\title{
Engineering-Scale Test 4: In Situ Vitrification of Toxic Metals and Volatile Organics Buried in INEL Soils
}

J. W. Shade

R. K. Farnsworth

J. S. Tixier

B. L. Charboneau

June 1991

Prepared for the U.S. Department of Energy under Contract DE-AC06-76RLO 1830

Pacific Northwest Laboratory

Operated for the U.S. Department of Energy

by Battelle Memorial Institute 


\title{
DISCLAIMER
}

This report was prepared as an account of work sponsored by an agency of the United States Government. Neither the United States Government nor any agency thereof, nor Battelle Memorial Institute, nor any of their employees, makes any warranty, expressed or implied, or assumes any legal liability or responsibility for the accuracy, completeness, or usefulness of any information, apparatus, product, or process disclosed, or represents that its use would not infringe privately owned rights. Reference herein to any specific commercial product, process, or service by trade name, trademark, manufacturer, or otherwise does not necessarily constitute or imply its endorsement, recommendation, or favoring by the United States Covernment or any agency thereof, or Battelic Memorial Institute. The views and opinions of authors expressed herein do not necessarily state or reflect those of the United States Government or any agency thereof.

\author{
PACIFIC NORTHWEST LABORATORY \\ operated by \\ BATTELLE MEMORIAL INSTITUTE \\ for the \\ UNITED STATES DEPARTMENT OF ENERGY \\ under Contract DE-ACO6.76RLO 1830
}

Printed in the United States of America

Available to DOE and DOE contractors from the

Office of Scientific and Technical Information, P.O. Box 62, Oak Ridge, TN 37831; prices available from (615) 576-8401. FTS 626-8401.

Available to the public from the National Technical Information Service, U.S. Department of Commerce, 5285 Port Royal Rd., Springfield, VA 22161. 
PNL-7611

UC -602

ENG INEERING-SCALE TEST 4:

IN SITU VITRIFICATION OF TOXIC METALS

AND VOLATILE ORGANICS BURIED IN INEL SOILS
J. W. Shade
R. K. Farnsworth (a)
J. S. Tixier
B. L. Charboneau (b)

June 1991

Prepared for

the U.S. Department of Energy

under Contract DE-ACO6-76RLO 1 B30

Pacific Northwest Laboratory

Richland, Washington 99352
(a) EG\&G Idaho, inc. Idaho Falls, Idaho
(b) Wastren, Inc.
Idaho Falls, Idaho 



\section{SUMMARY}

An engineering-scale in situ vitrification (ISV) test was conducted on soils containing a mixture of buried waste materials expected to be present at the Idaho National Engineering Laboratory (INEL) subsurface disposal area (SDA). The test was part of a Pacific Northwest Laboratory (PNL) ${ }^{(a)}$ program to assist INEL in treatability studies of the potential application of ISV to mixed transuranic wastes at the INEL SDA. The purpose of this test was to determine the feasibility of using ISV to vitrify soils containing a mixture of buried hazardous heavy metals ( $\mathrm{Ag}, \mathrm{As}, \mathrm{Ba}, \mathrm{Cd}, \mathrm{Cr}, \mathrm{Hg}, \mathrm{Pb}, \mathrm{Se}$ ), with stainless and carbon steels, nonhazardous combustibles, and organics in the form of cemented sludge/grease mixtures. Specific objectives included determining the destruction and removal efficiency of hazardous volatile organics, determining the distribution of hazardous heavy metals between vitrified components, soils, and the ISV off-gas system, determining the leachability of the vitrified product, and evaluating electrode coatings. Actual site soil from INEL was used in the test and a basalt block was placed at a depth of $66 \mathrm{~cm}$ (26 in.) below the soil surface. The basalt was included to simulate basalt layers below the SDA and to evaluate bonding of the glass to basalt and possible contaminant transport into the basalt.

A conservatively large volume of starter material was used in the test resulting in a startup time of $10.7 \mathrm{~h}$. Electrodes were gravity fed during the first $5 \mathrm{~h}$ until a short developed with the molten metal. The short was stopped by electrode feeding, which was used for the remainder of the test. The test ran for $41.1 \mathrm{~h}$ and achieved a melt depth of $79 \mathrm{~cm}$ (31 in.). It produced a $407-\mathrm{kg}$ block of vitrified soil. This compares favorably with engineering-scale test 3 in which electrode feeding was demonstrated, and which ran for $34.4 \mathrm{~h}$ with a melt depth of $89 \mathrm{~cm}$ (35 in.) and produced a $373-\mathrm{kg}$

(a) Pacific Northwest Laboratory is operated for the U.S. Department of Energy by Battelle Memoria1 Institute under Contract DE-AC06-76RLO 1830 . 
block of vitrified soi1. The average power input of the INEL SDA test was $14.2 \mathrm{~kW}$ compared with $16.0 \mathrm{~kW}$ for test 3 . The off-gas system adequately contained both volatiles and particulates.

The vitrified glass product passed both the Extraction Procedure Toxicity (EP Tox) and the Toxicity Characteristics Leach Procedure (TCLP) criteria for the EP Tox metals and organics. A soil/metal mixture containing 11.6 wt\% metal was placed at a depth between $10 \mathrm{~cm}$ and $51 \mathrm{~cm}(4$ to $20 \mathrm{in.}$ ). All of the metal was processed by the melt. The organic sludge/grease mixture was contained in a glass bottle to permit breakage prior to contact with the melt. The bottle reached a pressure of 8.6 psig before it breached $13.2 \mathrm{~h}$ after startup. At this time the melt depth was $20 \mathrm{~cm}(8 \mathrm{in.})$ and the temperature near the bottle was $200^{\circ} \mathrm{C}$. Following the test, the concentration of organics in the surrounding soil was several orders of magnitude below U.S. Environmental Protection Agency (EPA) limits for nonregulated waste and the same was observed for EP Tox and TCLP results of the soil. Of the EP Tox metals, Ba, $\mathrm{Cr}$, and $\mathrm{Pb}$ concentrations were highest in the vitrified $\mathrm{glass}$ but were still well below EPA-regulated waste limits. In the vitrified metal, leach test results for $\mathrm{Pb}$ in some samples indicated that some of the metal is above EPA limits. It is suspected that $\mathrm{Pb}$ may exist as a separate phase because of the reducing nature of the system and inability to alloy with other metals. Except for $C d$ in one soil sample near the melt, the EP Tox metals were below EPA limiting values for the soil samples. 


\section{CONTENTS}

SUMMARY

ii

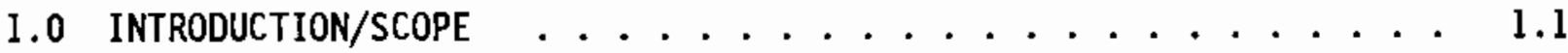

2.0 CONCLUSIONS . . . . . . . . . . . . . . . . . . . 2.1

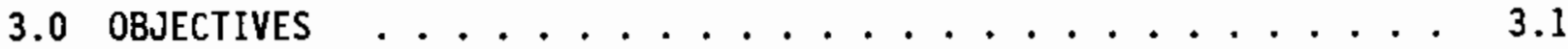

4.0 TEST AND SAMPLE ANALYSIS . . . . . . . . . . . . . . . . 4.1

4.1 TEST PREPARATION .......................... 4.1

4.2 SAMPLING . . . . . . . . . . . . . . . 4.5

4.2.1 Temperature Measurements ............. 4.5

4.2.2 Pretest Sampling ................. 4.5

4.2.3 Posttest Samples . . . . . . . . . . . . . . 4.6

4.2.4 Off-Gas Sampling ................ . 4.7

5.0 PROCESS RESULTS . . . . . . . . . . . . . . . . . 5.1

5.1 TEST PERfORMANCE ....................... 5.1

5.2 TEST RESULTS . . . . . . . . . . . . . . 5.3

5.3 EleCtRODE PERFORMANCE . . . . . . . . . . . 5.8

6.0 ANALYTICAL RESULTS AND INTERPRETATION . . . . . . . . . . . . 6.1

6.I ORGANIC CONSTITUENTS ..................... 6.1

6.2 EP TOX METALS ........................ 6.5

7.0 REFERENCES . . . . . . . . . . . . . . . . . . . . . . 7.1 


\section{FIGURES}

4.1 ES-INEL-4 Test Configuration .............. 4.2

4.2 ES-INEL-4 Pretest and Posttest Sample Locations . . . . . . 4.6

4.3 ES-INEL-4 Off-Gas MM5 Sample Train for Inorganics . . . . . 4.8

4.4 ES-INEL-4 Off-Gas MM5 Sample Train for Organics . . . . . . . 4.9

5.1 Glass Bottle Pressure Versus ISV Melt Depth ... . . . . . 5.2

5.2 Glass Bottle Pressure Versus Adjacent Soi1 Temperature . . . . . . 5.3

5.3 Vitrified Block Resulting from ES-INEL-4 . . . . . . . . 5.4

5.4 Electrical Test Data for ES-INEL-4 . . . . . . . . . . . 5.7

5.5 Melt Depth Versus Electrode Depth for ES-INEL-4 . . . . . . 5.9

5.6 Posttest Observation of Electrode Corrosion from ES-INEL-4 . . . 5.10

6.1 Comparison of $\mathrm{Pb}$ Oxidation with $\mathrm{Fe}$ 0xidation . . . . . . 6.9 


\section{TABLES}

4.1 Test Matrix for ES-INEL-4 . . . . . . . . . . . . . . 4.3

4.2 INEL Hazardous Waste Constituent Evaluation for the SDA . . . . 4.3

4.3 Material Chemical Additions to the ES-INEL-4 Test Soits . . . . 4.4

4.4 Simulated Organic Sludge Compositions for ES-INEL-4 . . . . . 4.4

5.1 Engineering Test Performance Comparison . . . . . . . . 5.5

6.1 Concentration of Organics in Posttest Soil Samples Surrounding the Melt ............. 6.2

6.2 TCLP-ZHE Analysis for Organics in Posttest Soils . . . . . . 6.3

6.3 Mass Balances of Volatile Organics . . . . . . . . . 6.4

6.4 Toxic Metal Concentrations in the Vitrified Glass from TCLP and EP Toxicity Testing . . . . . . . . . . . 6.6

6.5 EP Tox Metal Concentration Ranges in Glass . . . . . . . . 6.7

6.6 EP Tox Metals in the Metallic Phase . . . . . . . . . 6.8 6

6.7 Worst-Case EP Tox and TCLP Data for Posttest Soils . . . . . 6.10

6.8 Worst-Case Concentration of Toxic Metals in Posttest Soils . . . 6.11 



\subsection{INTRODUCTION/SCOPE}

An engineering-scale in situ vitrification (ISV) test using soils from Idaho National Engineering Laboratory (INEL) and components simulating selected buried waste materials at the INEL subsurface disposal area (SDA) was conducted to obtain additional information on the ISV processability of SDA buried waste and on the resultant ISV product quality. This test was designated ES-INEL-4 and had an electrode separation distance of $30 \mathrm{~cm}$ (12 in.). It was designed to evaluate processing parameters and product quality for melts from sites containing hazardous heavy metals, organics, nonhazardous combustibles, and steels. The migration of heavy metals and organics into the ISV system off gas and the soil surrounding the vitrification area was also evaluated. Samples were taken before, during, and after the ISV test and were analyzed to determine the extent of metal incorporation in the vitrified block, the amount of hazardous material migration (if any) away from the block, and the destruction and/or off-gas entrainment of hazardous materials

during processing. In addition, the test evaluated the ISV meit growth into a large piece of basalt rock. The basalt rock was included to simulate basalt layers below the SDA and to evaluate bonding of the glass to the basalt along with possible contaminant transport into the basalt.

Two standard leach tests, the Toxicity Characteristics Leach Procedure (TCLP) and the Extraction Procedure Toxicity (EP Tox) leach test, were conducted on samples of the contaminated pretest materials (cemented sludge/ grease and contaminated soils) and the vitrified block material (glass and meta1) produced by ES-INEL-4. In addition, pretest and posttest TCLP and EP Tox leach tests were performed on samples of the surrounding soil and the basalt rock layer beneath the melt. These data were used to determine the relative durability and product quality of the vitrified glass product and surrounding materials. The report also provides an evaluation of ISV system performance, electrode feed system performance, electrode coating performance, container pressurization, and ISV feasibility for buried waste sites with metals and organics. 
A] though not fully representative of a field-scale test, this engineering-scale test may be used in the selection and analysis of candidate remediation technologies for the SDA at INEL. ES-INEL-4 has been performed under Pacific Northwest Laboratory (PNL) Impact Level II Quality Assurance (QA) guidelines, using EPA Level 3, non-CLP 1aboratory methods. 


\subsection{CONCLUSIONS}

The ability of the ISV process to effectively process organics buried in sealed containers and to process buried EP Tox metals was demonstrated by ES-INEL-4. Although not fully representative of full-scale field testing conditions, this test provides a positive indication of the ability of the ISV technology to effectively treat sites containing organics and EP Tox metals. Key conclusions drawn from this test include the following:

- The resulting vitrified block produced a durable waste form with excellent qualities of heavy metal retention. The resulting block can be considered a nonregulated material based on TCLP and EP Tox test results.

- No significant transport of organics or EP Tox metals were observed in the soils surrounding the vitrified block. Only one soil sample immediately adjacent to the vitrified block yielded leach results for Cd that exceeded EPA limits but was below the limit for all other metals.

- The off-gas treatment system successfully contained all volatiles and particulates generated during the test.

- The volatile organics destruction/removal efficiency of greater than 99.9\% was determined for trichloroethylene and tetrachloroethylene. An improved sampling method is indicated for ether, trichloroethane, and carbon tetrachloride. The method used resulted in the breakthrough of the three volatile organics through the sorbent resin sampler tubes.

- The metal phase that resulted from the high metal content of the test satisfied leach test criteria for all EP Tox metals except lead. The apparent cause for the unsatisfactory leachability of lead is due to the formation of a separate lead phase. The largely ferrous metal product that was formed between the basalt rock and the vitrified block did not alloy with lead.

- The test successfully demonstrated the ability to vitrify through the waste layer and proceed to the underlying basalt. The resulting monolith solidly fused to the underlying block of basalt.

- Electrode feeding was necessary to recover from metallic shorting resulting from molten metal pools in the melt. The comparison of electrode coatings to minimize oxidation indicates that carbonvapor-deposited coatings limit oxidation better than painted coatings. Consistent with previous tests, on at least one occasion, the coatings on the electrodes contributed to an electrode becoming stuck to the glass for an extended period of time. 



\subsection{QBJECTIVES}

ES-INEL -4 was performed to determine the feasibility of using the ISV process to vitrify INEL soil that originally contained various concentrations of hazardous heavy metals, combustibles, other metals, and organics. The product quality, extent of contaminant destruction and release to the ISV offgas system, and the migration (if any) of contaminants into the soil surrounding the vitrified area were determined. The test used INEL soil, metals (consisting of $5.8 \mathrm{wt} \%$ stainless steel and $5.8 \mathrm{wt} \%$ carbon steel), combustibles ( 0.5 wt\% paper and 0.5 wt\% wood), eight heavy metals ( $\mathrm{Ag}, \mathrm{As}, \mathrm{Ba}, \mathrm{Cd}, \mathrm{Cr}$, $\mathrm{Hg}, \mathrm{Pb}$, and $\mathrm{Se}$ ), and two cemented sTudge/grease mixtures containing representative organics.

The engineering-scale ISV test was set up and performed successfully in accordance with the PNL test plan for ES-INEL-4. Sampling and analysis were performed in accordance with the EG\&G Idaho Sampling and Analysis Plan (SAP) for ES-INEL-4 (Charboneau et a7. 1989). The SAP for this test was designed to obtain preliminary data for the following objectives:

- Calculate what the destruction and removal efficiency of hazardous volatile organics would be if the ISV process were applied to the SDA.

- Calculate the percentages of heavy metals that would be incorporated into the me1t, deposited in the surrounding soil, and fluidized into the off gas if the ISV process were applied at the SDA.

- Calculate what the leachability of heavy metals would be in the vitrified product if the ISV process were applied at the SDA.

- Calculate the volume reduction the contaminated soil/waste would undergo if the ISV process were applied at the SDA.

- Calculate what the effectiveness of silicon carbide coatings would be on preventing electrode oxidation if the ISV process were applied at the SDA.

Finalized data relating to these objectives will be confirmed in future ISV tests. Results from ES-INEL- 4 will be used to design future ISV engineering tests that futly meet the above objectives. 


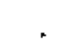




\subsection{TEST AND SAMPLE ANALYSIS}

\subsection{TEST PREPARATION}

The test was setup as shown in Figure 4.1 and described in the ES-INEL-4 test plan. A parametric matrix was established to summarize key parameters and system constraints for the test. Testing contaminants, soil moisture content, off-gas flow requirements, and combustible content limits are provided in Table 4.1 .

Table 4.2 gives a comparison of the hazardous waste constituents expected in the SDA site (as provided by EG\&G Idaho) and those used in the ES-INEL-4 test. Table 4.3 lists the amounts and form of the heavy metals and the amounts of metals and combustibles that were added to ES-INEL-4 according to the test plan. Table 4.4 shows the composition of the simulated batch of the sludge/grease mixture placed in the prepared test soil according to the test plan.

The basalt rock was placed such that its top surface was at a depth of $66 \mathrm{~cm}$ (26 in.), $15 \mathrm{~cm}$ (6 in.) below the bottom of the metal/soil mixture (see Figure 4.1). The eight inorganic EP Tox chemicals [barium carbonate, chrome (III) oxide, silver oxide, lead, cadmium oxide, arsenic trioxide, selenium dioxide, and mercury as listed in Table 4.3] were separately placed in the center of the metal/soil mixture at $5-\mathrm{cm}$ (2 in.) intervals, with barium carbonate (a nonvolatile EP Tox chemical) placed at the $15-\mathrm{cm}$ ( 6 in.) level, and mercury (the most volatile EP Tox metal) placed at the $51-\mathrm{cm}$ (20 in.) level. A11 but the mercury were loosely placed in the metal/soil mixture. The mercury was placed in a small glass bottle that was expected to break before it came into contact with the ISV melt front.

The sludge/grease mixture, containing carbon tetrachloride $\left(\mathrm{CCl}_{4}\right)$, trichloroethylene (TCE), tetrachloroethylene (PCE), trichloroethane, and ethyl ether (as shown in Table 4.4), was placed in a half-gallon glass bottle that was inverted in the center of the metal soil mixture with the top of the bottle at a $51-\mathrm{cm}$ (20 in.) depth and the bottom of the bottle at a $27-\mathrm{cm}$ (10.5 in.) depth. The glass bottle was chosen to allow breakage of the container and subsequent movement of the sludge/grease mixture before it came 


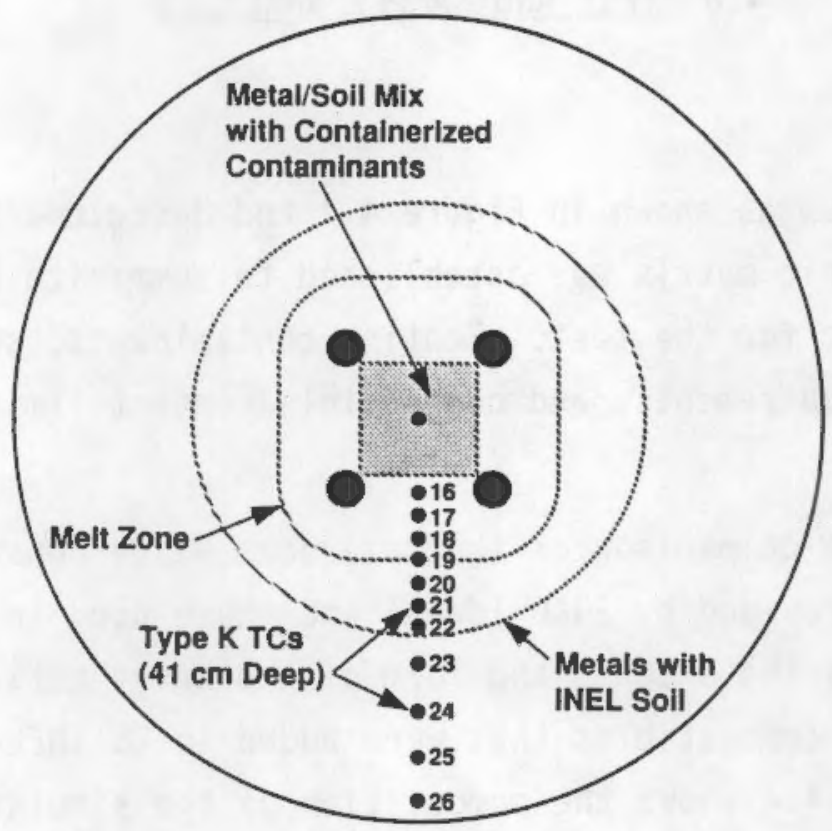

Radius, cm (in.)

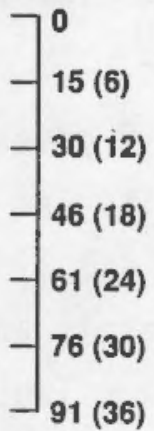

Ion Vlew

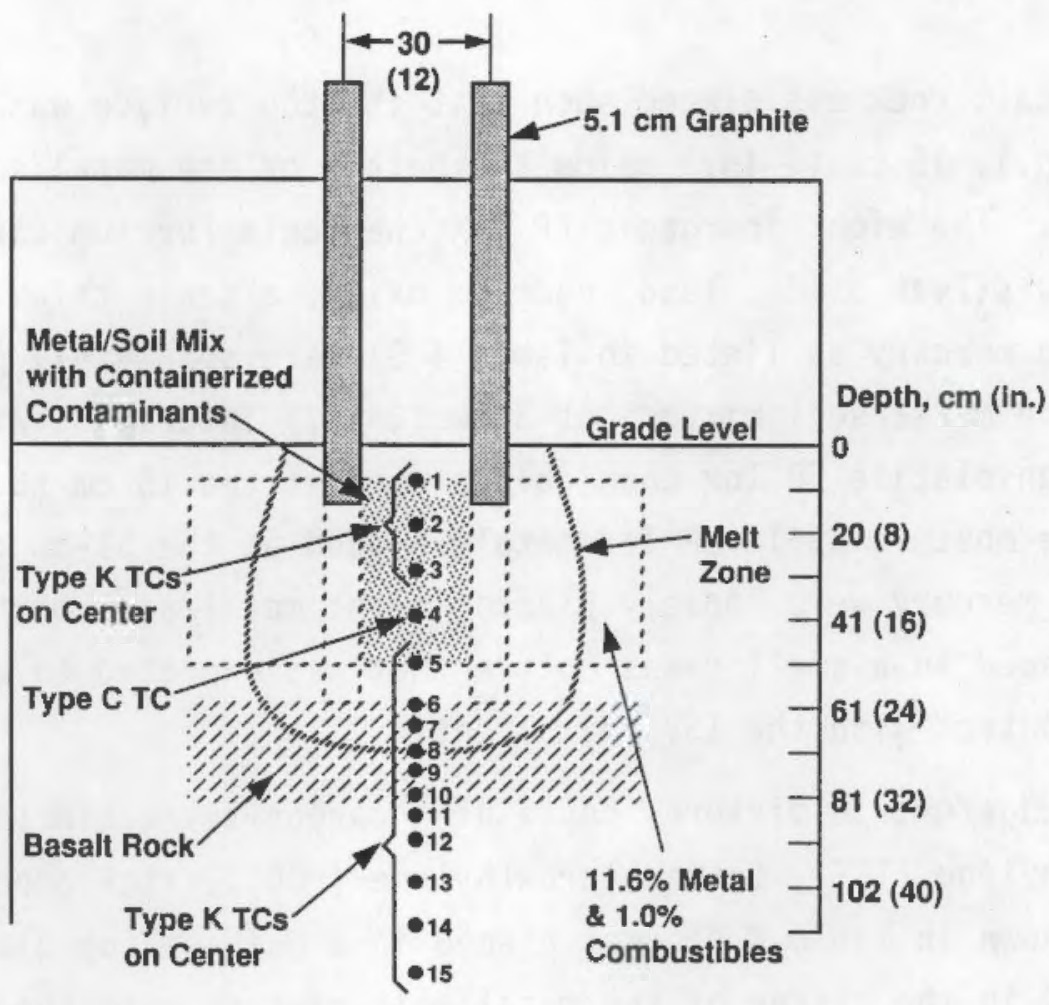

Side View

FIGURE 4:1. ES-INEL-4 Test Configuration 
TABLE 4.1. Test Matrix for ES-INEL-4

Contaminants and Additives

Moisture Content

Off-Gas Flow

System

Inorganic Sampling

Organic Sampling

Combustible limit (based on

flow, $100 \%$ excess air and

design factor of 2)
See Tables 4.2,

4.3 and 4.4

$-11 \%$

$21 \mathrm{scfm}$

$13 \mathrm{~L} / \mathrm{min}$

$50 \mathrm{~mL} / \mathrm{min}$

$15 w t \%$

TABLE 4.2. INEL Hazardous Waste Constituent Evaluation for the SDA

\begin{tabular}{|c|c|c|}
\hline Hazardous Compound & $\begin{array}{r}\text { Wt\% in } \\
\text { Site } \\
\end{array}$ & $\begin{array}{r}W t \% \text { in } \\
\text { Test } \\
\end{array}$ \\
\hline $\begin{array}{l}\mathrm{Pb} \\
\mathrm{Ag} \\
\mathrm{As} \\
\mathrm{Ba} \\
\mathrm{Cd} \\
\mathrm{Cr} \\
\mathrm{Hg} \\
\mathrm{Se}\end{array}$ & $\begin{array}{l}0.023 \\
\text { TBD } \\
\text { TBD } \\
\text { TBD } \\
\text { TBD } \\
\text { TBD } \\
\text { TBD } \\
\text { TBD }\end{array}$ & $\begin{array}{l}0.2 \\
0.02 \\
0.02 \\
0.02 \\
0.02 \\
0.02 \\
0.02 \\
0.02\end{array}$ \\
\hline Sludge/Grease $^{\text {(b) }}$ & 0.4 & 1.3 \\
\hline $\begin{array}{l}\text { Texaco Regal } 0 i 1 \\
\text { CCl } \\
0 i 1^{4} \\
\text { Ether } \\
\text { l, } 1,1 \text {-trichloroethane } \\
\text { TCE } \\
\text { PCE } \\
\text { Alcohols } \\
\text { Organic Acids } \\
\text { Versene (EDTA soln, } \\
\text { lathe coolant) }\end{array}$ & $\begin{array}{l}25.2 \\
28.0 \\
10.2 \\
2.82 \\
4.66 \\
4.03 \\
4.30 \\
4.90 \\
7.35 \\
8.58\end{array}$ & \\
\hline
\end{tabular}

(a) To be determined.

(b) $\mathrm{Wt} \%$ values given refer to percent of component present in sludge/grease. 
IABLE 4.3. Material Chemical Additions to the ES-INEL-4 Test Soils

\begin{tabular}{|c|c|c|}
\hline Mixture & Compound & Amount \\
\hline Meta1-Soil & $\begin{array}{l}\text { INEL Soil } \\
\text { Stainless Stee1 } \\
\text { Carbon Steel } \\
\text { Paper } \\
\text { Wood }\end{array}$ & $\begin{array}{l}286.4 \mathrm{~kg} \\
19.51 \mathrm{~kg} \\
19.51 \mathrm{~kg} \\
1682 \mathrm{~g} \\
1682 \mathrm{~g}\end{array}$ \\
\hline EP Tox Metals & $\begin{array}{l}\mathrm{Pb} \text { (Metal) } \\
\mathrm{Cr}_{2} \mathrm{O}_{3} \\
\mathrm{BaCO}_{3} \\
\mathrm{SeO}_{2} \\
\mathrm{As}_{2} \mathrm{O}_{3} \\
\mathrm{CdO}^{2} \\
\mathrm{Ag}_{2}{ }^{\mathrm{O}} \\
\mathrm{Hg}^{2} \text { (Metal) }\end{array}$ & $\begin{array}{r}700.0 \mathrm{~g} \\
102.3 \mathrm{~g} \\
100.6 \mathrm{~g} \\
98.4 \mathrm{~g} \\
92.4 \mathrm{~g} \\
\mathrm{B0} .0 \mathrm{~g} \\
75.2 \mathrm{~g} \\
70.0 \mathrm{~g}\end{array}$ \\
\hline Organic Sludge/Grease & & $\begin{array}{l}(0.4 \mathrm{gal}) \\
1514 \mathrm{~mL}\end{array}$ \\
\hline
\end{tabular}

TABLE 4.4. Simulated Organic Sludge Compositions for ES-INEL-4 (includes pretest samples)

Batch 1

Mixed with $(\mathrm{a})$

(includes

$825 \mathrm{~mL}$ of

analytical

pretest

samples)
Component

\begin{tabular}{l} 
Component \\
\hline Texaco Regal 0i1 \\
(R\&0 68, Segal 10193) \\
CCl 4 . \\
Unocal Soluble 0i1 \\
10 (cutting fluid) \\
Ethyl Ether \\
1,1,1-trichloroethane \\
PCE \\
TCE
\end{tabular}

Total
Vol \% Volume, $\mathrm{mL}$ Weight, $\mathrm{g}$

$31.7 \quad 279$

254.7

$19.9 \quad 174$

$12.8 \quad 113$

278.1

103.2

$4.53 \quad 40$

4.07

35

3.05

3.05

79.1
27

27

695
28.5

48.3

39.3

43.8

795.9

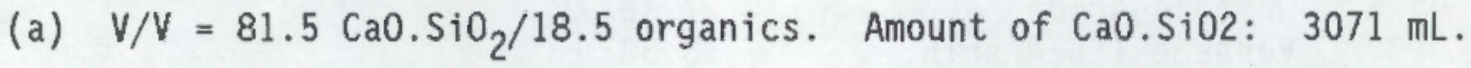

into contact with the vitrified melt. To determine the internal pressure of the container and the time of container fracture, a pressure transducer was plumbed into the lid of the glass bottle containing the sludge/grease mixture. At the time of burial, the sludge/grease mixture had not yet solidified due to the inability of the sealed container to evaporate any water. 


\subsection{SAMPLING}

\subsubsection{Temperature Measurements}

To monitor the melt progress, Type $K$ thermocouples were installed at the center line between the electrodes starting $10 \mathrm{~cm}(4 \mathrm{in.})$ below the soil surface and at $10 \mathrm{~cm}(4 \mathrm{in.})$ and $5 \mathrm{~cm}$ ( 2 in.) intervals as shown in Figure 4.1. A high-temperature, Type $C$ thermocouple, located at a depth of 16 in. and $8 \mathrm{~cm}$ ( 3 in.) off the center line between the electrodes, was used to monitor actual melt temperatures hourly during the test. A string of Type $K$ thermocouples, at $7.5-\mathrm{cm}$ and $3.8-\mathrm{cm}$ ( 3 and $1.5 \mathrm{in.}$ ) intervals, was installed at the same depth as the Type $C$ thermocouple. A chart recorder was used to status and record all preplaced thermocouples at least once every five minutes during the test.

Placement of the vertical thermocouples was complicated by the presence of the basalt rock beneath the ISV melt area. To prevent the effect of holes in the basalt rock on possible inorganic or organic material migration, the thermocouple holes through the basalt rock were drilled at a $55^{\circ}$ angle with the top of the hole $15 \mathrm{~cm}$ ( 6 in.) away from the center of the melt. As a result, all of the thermocouples at a $61-$ to $85-\mathrm{cm}$ (24 to $33.5 \mathrm{in}$.) depth were placed 17 to $34 \mathrm{~cm}$ (6.6 to 13.3 in.) off center. This configuration will affect the interpretation of temperature isotherm data beneath the block.

\subsubsection{Pretest Sampling}

Pretest soil samples were obtained during construction of the ISV system. These samples were taken from the same soil locations designated for the posttest sampling, as shown in Figure 4.2. The pretest soil was sampled to determine the background levels of the organics and EP Tox metals, as well as to determine the soil composition so as to further define the actual test conditions.

The sludge/grease mixture also had pretest samples taken to determine the actual concentration of volatile organics and trace EP Tox metals after final sludge preparation was completed. The sludge/grease mixtures were also analyzed separately for their hazardous constituents, if any. 


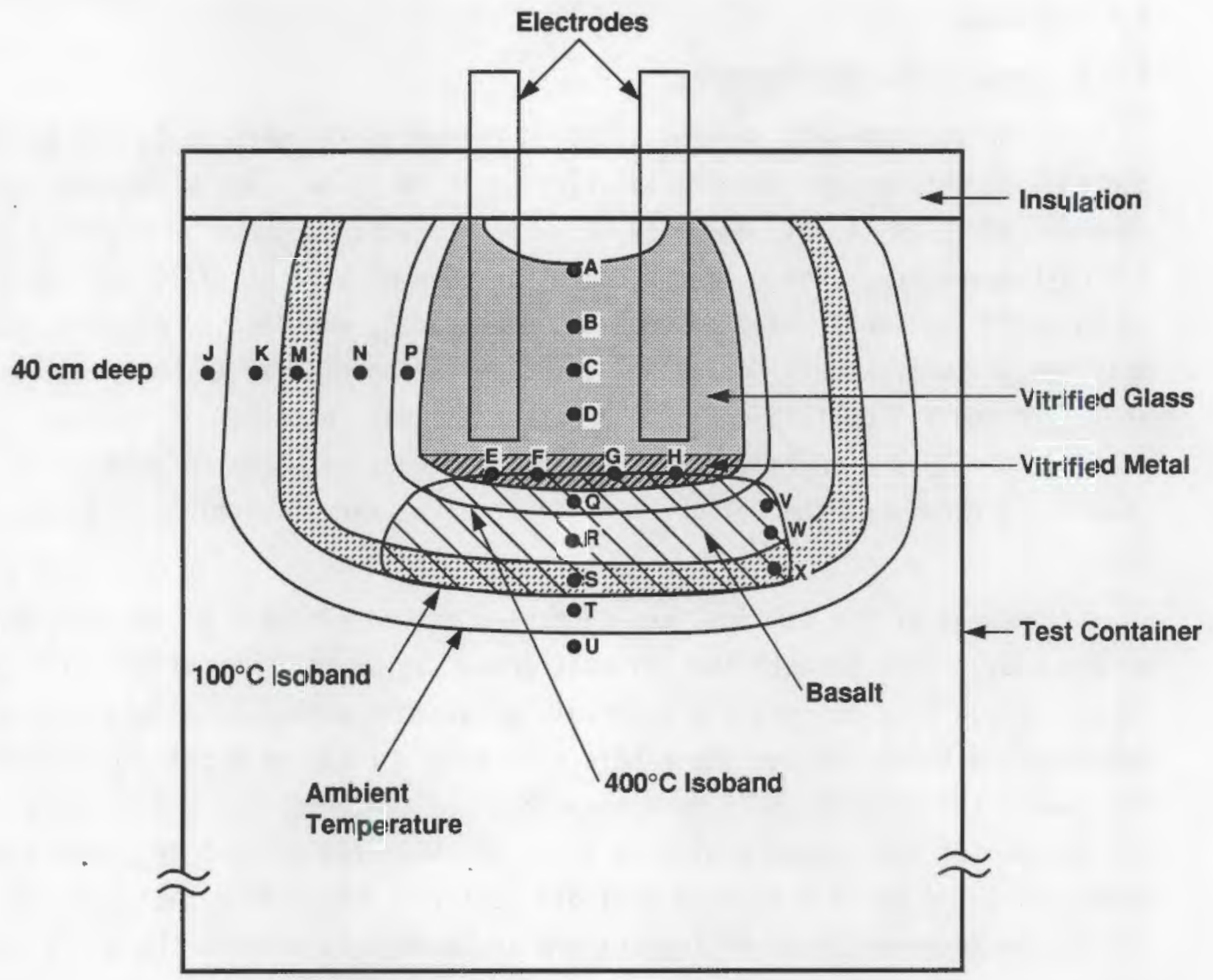

Sample locations shown as

Samples consist of a composite within the "band" of soil as indicated by the sample location. The soil sample below the ambient temperature band extends to $2^{\circ}$ below the band.

39105103.1

FIGURE 4.2. ES-INEL-4 Pretest and Posttest Sample Locations

\subsubsection{Posttest Samples}

After ES-INEL- 4 was completed, samples of the vitrified material, the soil adjacent to the vitrified zone, and soil out to the edge of the ISV system container were obtained. Posttest soil sampling on the side of the vitrified block was hampered by burnout of the horizontal thermocouples when 
the electrodes were removed from the melt just prior to test shutdown. To minimize soil disturbance, the soil was removed in layers until the bottom of the vitrified block was exposed. The block was then removed, and the soil underneath the block removed and sampled layer by layer based on thermocouple readings. Special care was taken during soil sampling to prevent cross contamination. Different containers were used for each soil sample and the

gloves used for collecting the samples were changed between each sample. Core samples of the glass block and basalt rock were taken at four different vertical positions. Figure 4.2 shows the approximate locations where the surrounding soil samples, basalt rock, and glass samples were taken. Samples of the lid blanket insulation and smears of the engineering-scale container lid were also analyzed.

\subsubsection{Off-Gas Sampling}

Off gas from the vitrification zone was sampled continuously during the test. A fraction $(13 \mathrm{~L} / \mathrm{min})$ of the total off-gas flow was drawn isokinetically into a Modified Method 5 (MM5) sampling train that was used for sampling the EP Tox metal effluents and entrained particulate that is sent to the offgas system during ISV processing.

The off-gas trains for sampling the organics consisted of two sorbent resin tubes of activated carbon, through which a smal1 fraction $(50 \mathrm{~mL} / \mathrm{min})$ of the total off-gas flow was drawn. The first tube was used to capture most of the organics, while the second tube was supposed to capture any residual organics.

The inorganic and organic off-gas trains are depicted in Figures 4.3 and 4.4 , respectively. Further information about the off-gas sampling is contained in SW-846 Test Method 0010. 


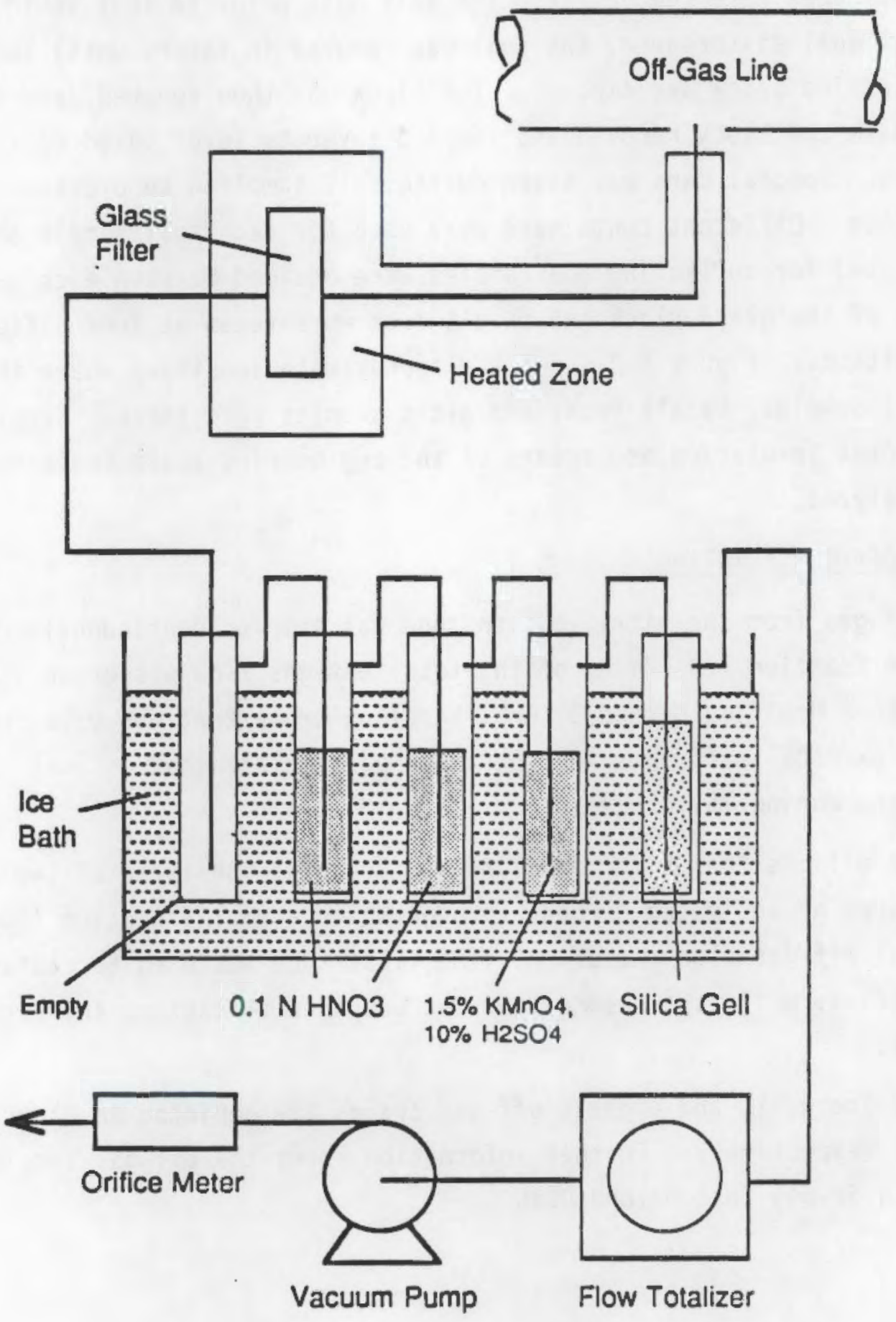

FIGURE 4.3: ES-INEL-4 Off-Gas MM5 Sample Train for Inorganics 


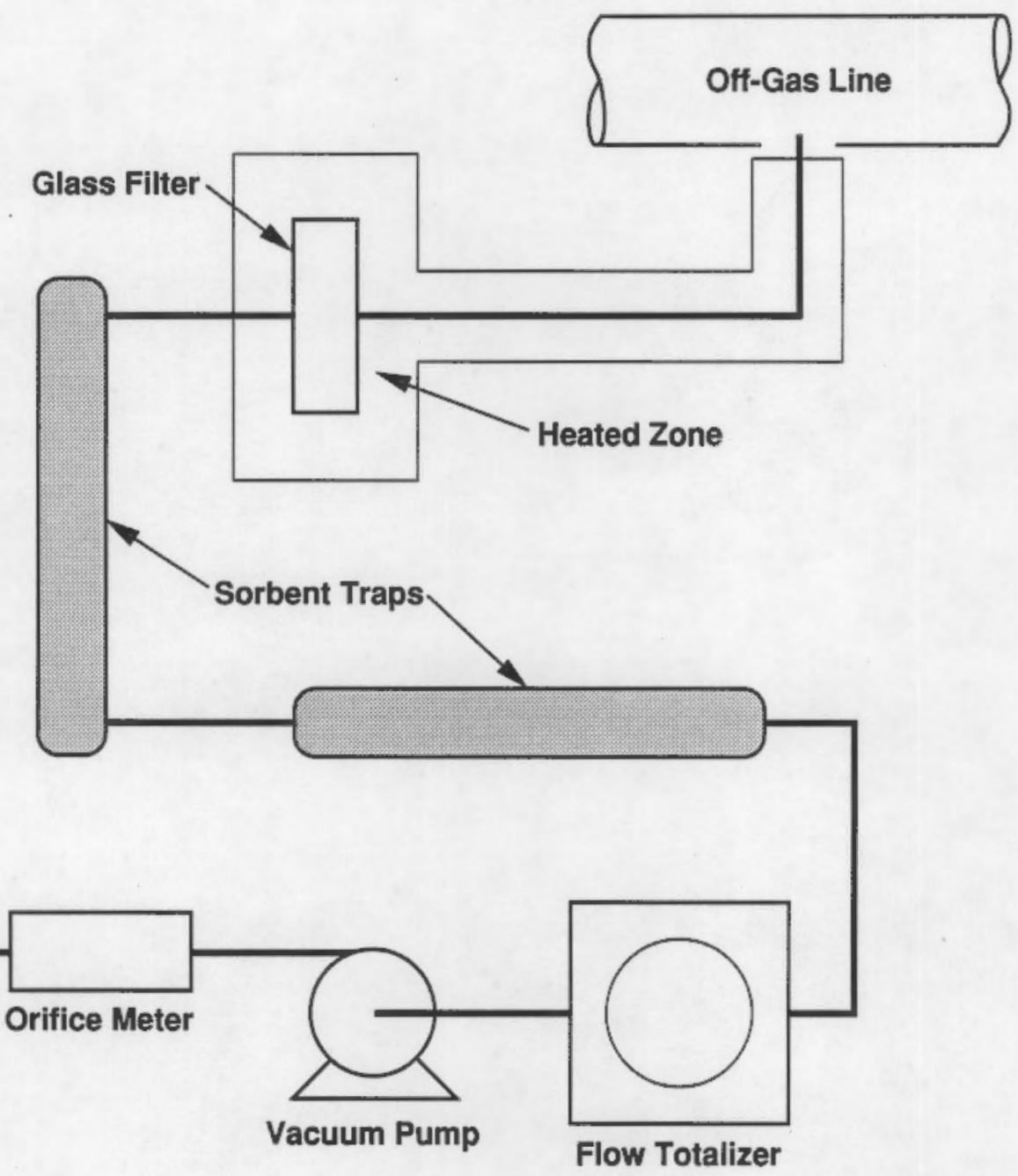

39105103.3

FIGURE 4.4. ES-INEL-4 off-Gas MM5 Sample Train for Organics 



\subsection{PROCESS RESULTS}

The fourth engineering test on INEL soils (ES-INEL-4) was started at 11:13 a.m. on December 19, 1989, and completed at 4:20 a.m. on December 21, 1989. The test was performed in accordance with PNL Test Plan ES-INEL-4, Rev. 1 (September 1989), INEL Sampling and Analysis Plan EGG-WM-8662 (September 1989), and PNL Technical Sampling Procedure for Engineering-Scale ISV Tests (PNL-ISV-1, December 1989). The resultant ISV block had a total mass similar to that from the third engineering test (Farnsworth et al. 1990) and fused with the large piece of basalt rock that was underneath the vitrified test area.

\subsection{TEST PERFORMANCE}

The engineering test achieved a melt depth of $79 \mathrm{~cm}$ (31 in.) before it was completed ( $41.1 \mathrm{~h}$ after start-up). The test had a start-up time of $10.7 \mathrm{~h}$. A conservatively large volume of starter material, measuring $5 \mathrm{~cm} x$ $4 \mathrm{~cm}$ ( 2 in. $x 1.5$ in.), was placed in the "crossed square" pattern between the electrodes [the typical starter path has a $2.5 \mathrm{~cm} \times 2.5 \mathrm{~cm}$ (1 in. $\times 1$ in.) cross section]. While not optimum for rapid start-up, this conservative loading minimized the possibility of starter path failure. After completing start-up, the engineering test reached a depth of approximately $65 \mathrm{~cm}$ (25.5 in.) in the next $18.4 \mathrm{~h}$, only $1 \mathrm{~cm}(0.5 \mathrm{in}$.) away from the top surface of the basalt rock. During this period, one of the silicon carbide (SiC)painted electrodes became stuck at the $30-\mathrm{cm}(12 \mathrm{in.})$ depth for approximately $6 \mathrm{~h}$ (15.7 $\mathrm{h}$ after start-up). However, $21.7 \mathrm{~h}$ after start-up the stuck electrode freed itself from the viscous glass (via electrode feeding) and was inserted another $15 \mathrm{~cm}$ ( 6 in.) into the ISV melt, at the same level as the other three electrodes.

During the initial portion of the test, the ISV melt processed the eight EP Tox metals and the sludge/grease mixture such that the resultant glass product passed both the EP Tox and TCLP criteria. Pressure transducer data indicated that the glass bottle containing the sludge/grease mixture reached a pressure of $8.6 \mathrm{psig}$ before it breached, $13.2 \mathrm{~h}$ after test start-up. At this 
time, the ISV melt had reached a depth of approximately $20 \mathrm{~cm}$ (8 in.), and the temperature of the soil directly adjacent to the inverted bottom of the glass bottle was approximately $200^{\circ} \mathrm{C}$ (see Figures 5.1 and 5.2). This shows that the organic materials contained in the glass bottle were free to move prior to being contacted by the melt. Persistent flares, appearing to be pressurized gas venting, were observed at the melt surface during this time and may have resulted from the burning organic vapors.

The ISV melt also processed the $11.6 \mathrm{wt} \%$ metal present in the metal/soil mixture that was placed between the $10-\mathrm{cm}(4 \mathrm{in.})$ and $51-\mathrm{cm}(20 \mathrm{in.})$ depth. The electrode feed system allowed the electrodes to be raised above the molten metal pool that formed at the bottom of the melt during ISV processing. The electrodes were gravity fed to the melt for approximately $5 \mathrm{~h}$ until a short was encountered, approximately $15 \mathrm{~h}$ after start-up. (This had no effect on the test.) The electrode feeding was then operator-controlled through the remainder of the test. This illustrates how electrode feeding can accommodate various processing conditions.

Power to the test was discontinued for $2.1 \mathrm{~h}, 29.1 \mathrm{~h}$ after start-up,. to repair the power controller. During this period, the temperature of the molten ISV glass dropped from $1300^{\circ} \mathrm{C}$ to $1107^{\circ} \mathrm{C}$. Because of the hardening of the molten glass, the electrodes in the melt became stuck during this time

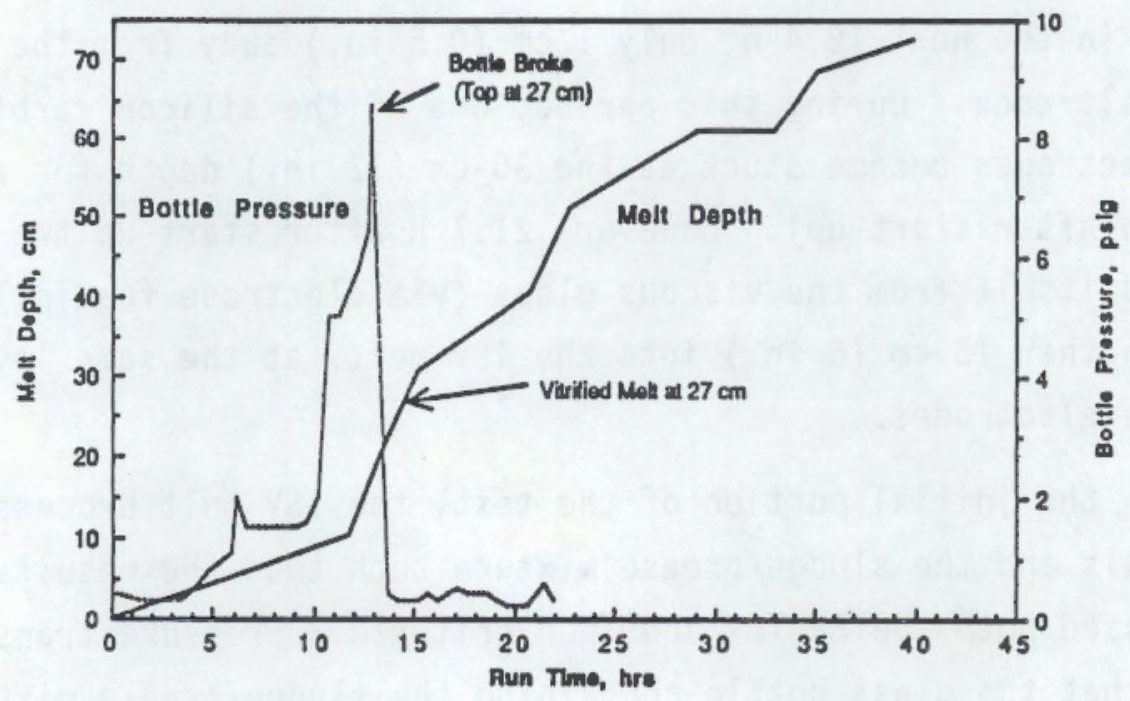

FIGURE 5.1. Glass Bottle Pressure Versus ISV Melt Depth 


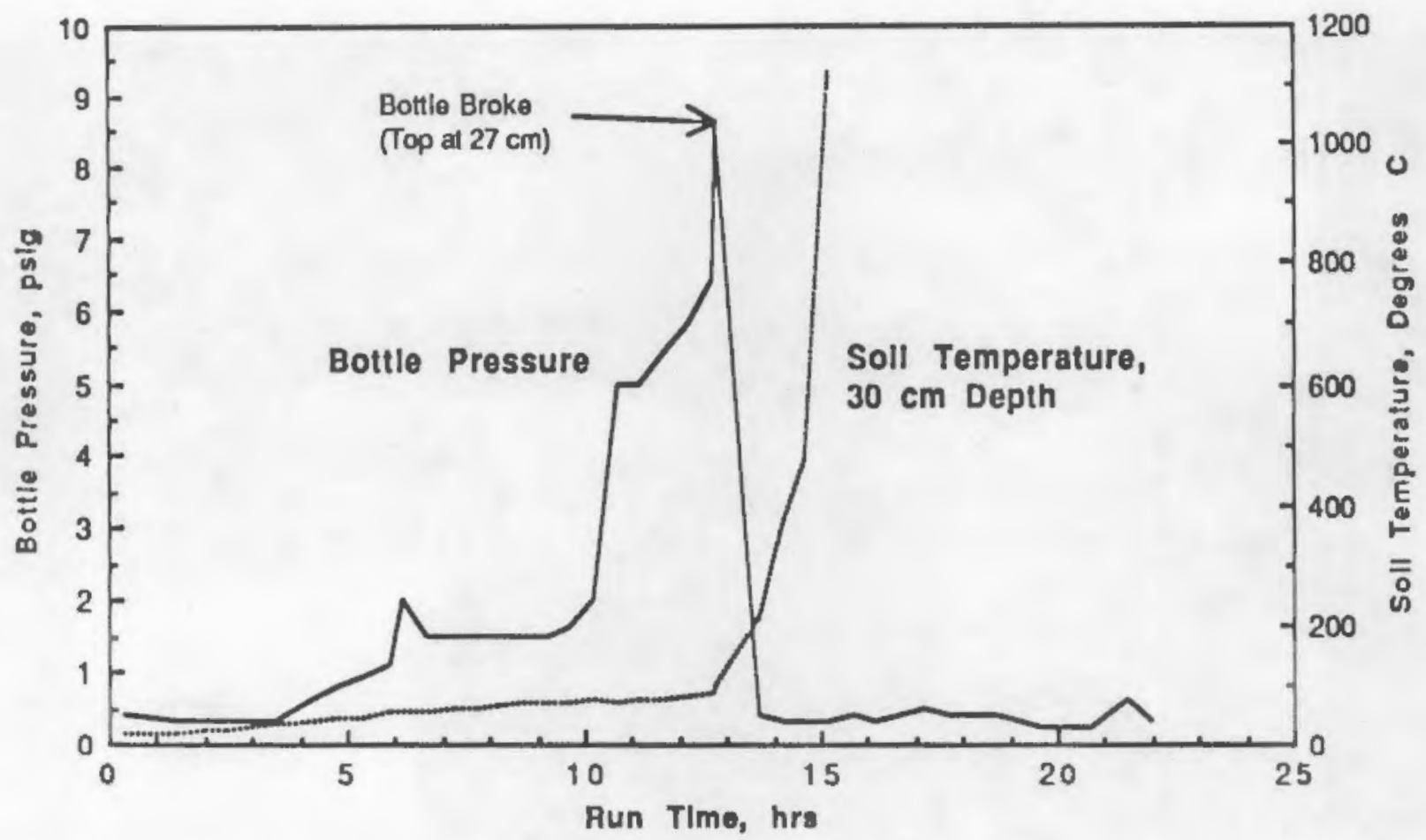

FIGURE 5.2. Glass Bottle Pressure Versus Adjacent Soil Temperature

and rose approximately $5 \mathrm{~cm}$ ( 2 in.) before power was restored. The raise in electrodes may be the result of the hardening glass, which becomes less dense. Upon fixing the power controller, power was restored to the ISV melt; it restarted with ease, and the electrodes freed themselves $2 \mathrm{~h}$ later.

After restoring power, the melt was continued for another $9.8 \mathrm{~h}$. Power was discontinued $1 \mathrm{~h}$ after the thermocouple located $73 \mathrm{~cm}$ (29 in.) deep and $25 \mathrm{~cm}(9.8 \mathrm{in.})$ off center had reached $1200^{\circ} \mathrm{C}$. Before shutting off power, the A-phase electrodes were inserted to a depth of $72 \mathrm{~cm}(28 \mathrm{in.})$; all four of the electrodes were then raised out of the melt using the electrode feed system.

\subsection{IEST RESULTS}

A photograph of the vitrified block is shown in Figure 5.3. The vitrified block weighed approximately $407 \mathrm{~kg}(898 \mathrm{lb})$. During ISV processing, the block reached a depth of $79 \mathrm{~cm}$ (31 in.) and a width of $81 \mathrm{~cm}(32 \mathrm{in.}$ ), with 


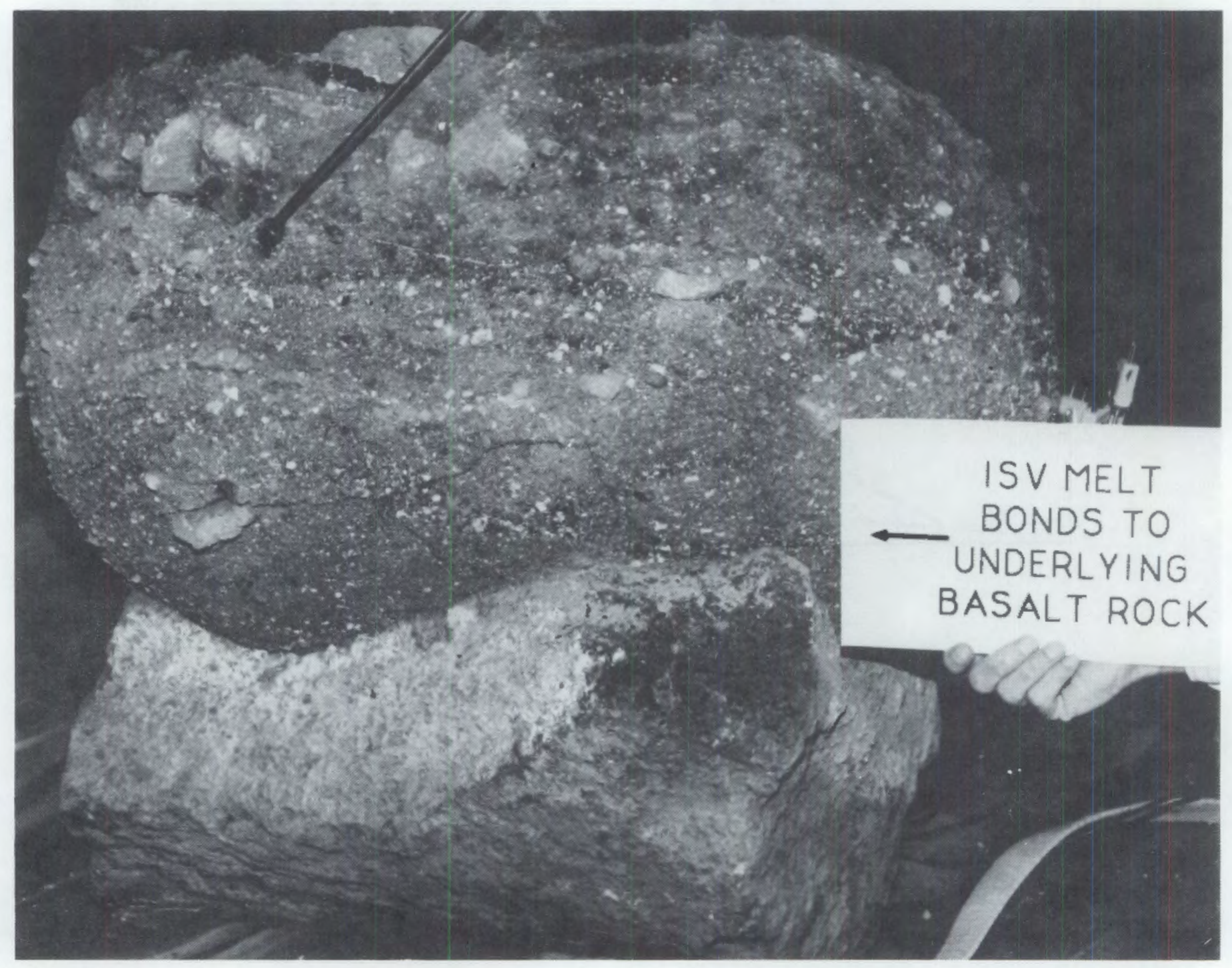

FIGURE 5.3. Vitrified Block Resulting from ES-INEL-4

full surface subsidence to a depth of $38 \mathrm{~cm}$ (15 in.). Because of the hazardous nature of the melt, subsidence measurements of vitrified melt could not be taken during testing as originally planned. Instead, final melt subsidence was measured after the vitrified block had cooled. The amount of fused glass above the subsided surface was completely broken up by the removal of the four electrodes during this test. Assuming that none of the metal was oxidized and dissolved in the glass, mass balance of the metal remaining in the soil indicated that the vitrified block had a total steel concentration of $9.4 \%$. 
TABLE 5.1. Engineering Test Performance Comparison

\begin{tabular}{|c|c|c|}
\hline Parameter & ES-INEL-3 & ES-INEL-4 \\
\hline Total Run Time & $34.4 \mathrm{~h}$ & $41.1 \mathrm{~h}$ \\
\hline Time at Full Power & $23.9 \mathrm{~h}$ & $25.9 \mathrm{~h}$ \\
\hline Total Energy & $550 \mathrm{kWh}$ & $585 \mathrm{kWh}$ \\
\hline Average Power & $16.0 \mathrm{~kW}$ & $14.2 \mathrm{~kW}$ \\
\hline Average, Full Power & $20.8 \mathrm{~kW}$ & $20.3 \mathrm{~kW}$ \\
\hline Melt Depth & $0.89 \mathrm{~m}$ (35 in.) & $0.79 \mathrm{~m}$ (31 in.) \\
\hline Melt Width & $0.77 \mathrm{~m}$ (30 in.) & $0.81 \mathrm{~m}$ (32 in.) \\
\hline Surface Subsidence & $0.51 \mathrm{~m}(20$ in. $)$ & $0.38 \mathrm{~m}$ (15 in.) \\
\hline Vitrified Glass Weight & $373 \mathrm{~kg}$ & $407 \mathrm{~kg}$ \\
\hline Soil Vitrified (est.) & $418 \mathrm{~kg}$ & $456 \mathrm{~kg}$ \\
\hline Energy-to-Mass Ratio & $1.3 \mathrm{kWh} / \mathrm{kg}$ & $1.3 \mathrm{kWh} / \mathrm{kg}$ \\
\hline Metals Content & $12.4 \mathrm{wt} \%$ & $9.4 w t \%$ \\
\hline
\end{tabular}

Performance data for ES-INEL-4 are shown in Table 5.1. For comparison purposes, the performance data for the third engineering test of INEL soils (Farnsworth et al. 1990) is also shown. The data show that the vitrified blocks for each of these two tests are relatively similar, with the ES-INEL-4 block being slightly larger, wider, and less deep than the block from ESINEL-3. The total amount of energy to the two blocks differed by less than $5 \%$.

The presence of a basalt block at the bottom of the vitrified test area probably contributed to the wider, shallower melt that was produced during ES-INEL-4. Upon encountering the basalt, the rate of downward melting was slowed, while the rate of outward growth was increased. This was due to the influence of particle size on melt growth. Because of its solid nature, more energy is needed to incorporate the basalt into the melt than is needed for the surrounding soils that are horizontal to the melt. Nevertheless, the basalt rock was incorporated in the melt to the extent that it adhered to the mineral and volcanic glass components in the rock. The measured temperature was sufficient for partial melting of the basalt to occur and fuse with the ISV melt. 
Four metal pools formed in the vitrified block between the glass and the basalt rock directly beneath where the graphite electrodes used to be. The presence of four metal pools instead of one was probably due to the lack of joule heating in the center bottom of the melt, relative to the high amount of joule heating that occurred between the electrodes and the metal pools. The metal pools appeared to be completely homogeneous.

The energy-to-mass ratio of the resultant block was $1.3 \mathrm{kWh} / \mathrm{kg}$ of soil. This is equivalent to the energy-to-mass ratio for the ES-INEL-3 block (see Table 5.1). These energy-to-mass ratios are slightly higher than typical ISV melt ratios of 0.8 to $1.1 \mathrm{kWh} / \mathrm{kg}$ of soil, but similar to the other engineering-scale tests (ES-INEL-1 and ES-INEL-2) that involved fixed electrodes (Oma, Reimus, and Timmerman 1989). The increased energy-to-mass ratios are probably due to the higher melting temperatures of INEL soils.

Power to the electrodes was controlled to provide an accurate scaledown of the cross-sectional power density from the large-scale ISV system. During full-power operations, the average power to the engineering test was $20.3 \mathrm{~kW}$. This results in an average power density of $219 \mathrm{~kW} / \mathrm{m}^{2}$, which is equivalent to the nominal power density for a large-scale system with a $4-\mathrm{m}$ spacing. As a result, the downward growth of the ISV melt through the zones of inorganic and organic contamination should be similar to that which would be encountered in the large-scale ISV system. Therefore, the rate of inorganic and organic material movement in ES-INEL-4 should be similar to that of a large field test.

Electrical data for ES-INEL-4 are illustrated in Figure 5.4. As with ES-INEL-3, the measured voltages, amperages, and resistances were relatively balanced between electrical phases.

The maximum temperatures recorded by the Type $c$ thermocouple, which was located $41 \mathrm{~cm}$ (16 in.) deep and approzimately $8 \mathrm{~cm}(3 \mathrm{in.}$ ) off the center of the melt, was $1601{ }^{\circ} \mathrm{C}$ at $39.7 \mathrm{~h}$ after start-up. As a result, it is expected that the operating temperatures were high enough to produce a high-quality vitrified product. 

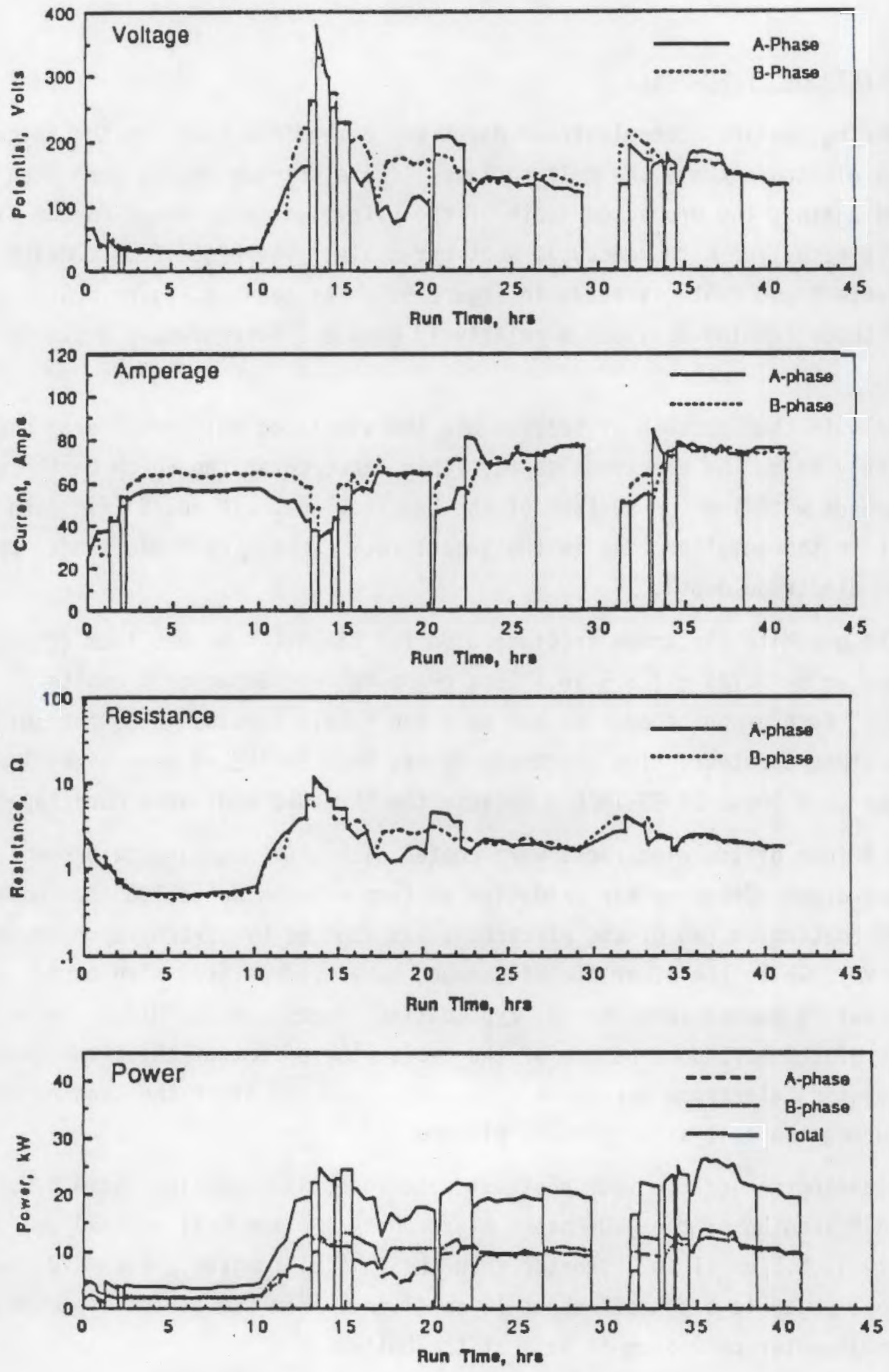

FIGURE 5.4. Electrical Test Data for ES-INEL-4 


\subsection{ELECTRODE PERFORMANCE}

During testing, the electrode depth was determined based on the height of each electrode above the melt surface. The electrode depths were then plotted against the projected depth of the vitrified melt, based on the time at which each Type $K$ thermocouple went off-scale. The plot of melt depth versus electrode depth is shown in Figure 5.5. As seen in Figure 5.5, the use of electrode feeding provides a relatively good estimate of melt depth in INEL soils.

Only in the last $8 \mathrm{~h}$ of testing did the vitrified melt depth drop significantly below the electrode depth. This occurred at the $60-\mathrm{cm}$ depth, which corresponds with the top surface of the basalt block. It could have been due in part to the metal pooling in the basalt rock beneath each electrode, which limited electrode depth.

The graphite electrode sections used for ES-INEL-4 were $5.1 \mathrm{~cm}$ (2 in.) in diameter by $0.724-m-(28.5$ in.) long grade MR from Superior Graphite Company. Each graphite section had male and female threaded ends for joining the sections together. The electrode joints from ES-INEL-4 were significantly stronger than those of ES-INEL-3 because the threaded ends were more tapered.

All four of the electrodes were coated with a SiC coating to protect the graphite electrodes from air oxidation at temperatures up to $1000^{\circ} \mathrm{C}$. However, the SiC coating on two of the electrodes was applied by carbon vapor deposition (CVD), while the other two electrodes were hand-painted with three coats of SC coating manufactured by the Zyp Coating Company of Oak Ridge, Tennessee. Because of the hazardous nature of the tests, the effect of these two coatings on preventing electrode corrosion rates was evaluated after the test rather than during the test as originally planned.

A photograph of the four posttest electrodes is shown in Figure 5.6. The final lengths of the CVD-coated electrodes (A-1 and B-1) were $70 \mathrm{~cm}$ (27.5 in.), $2.5 \mathrm{~cm}$ (1 in.) shorter than the initial lengths. Each CVD-coated electrode began to taper off about $18 \mathrm{~cm}$ ( 7 in.) from the bottom, reaching a minimum diameter of $2.5 \mathrm{~cm}$ ( 1 in.) at the bottom. 


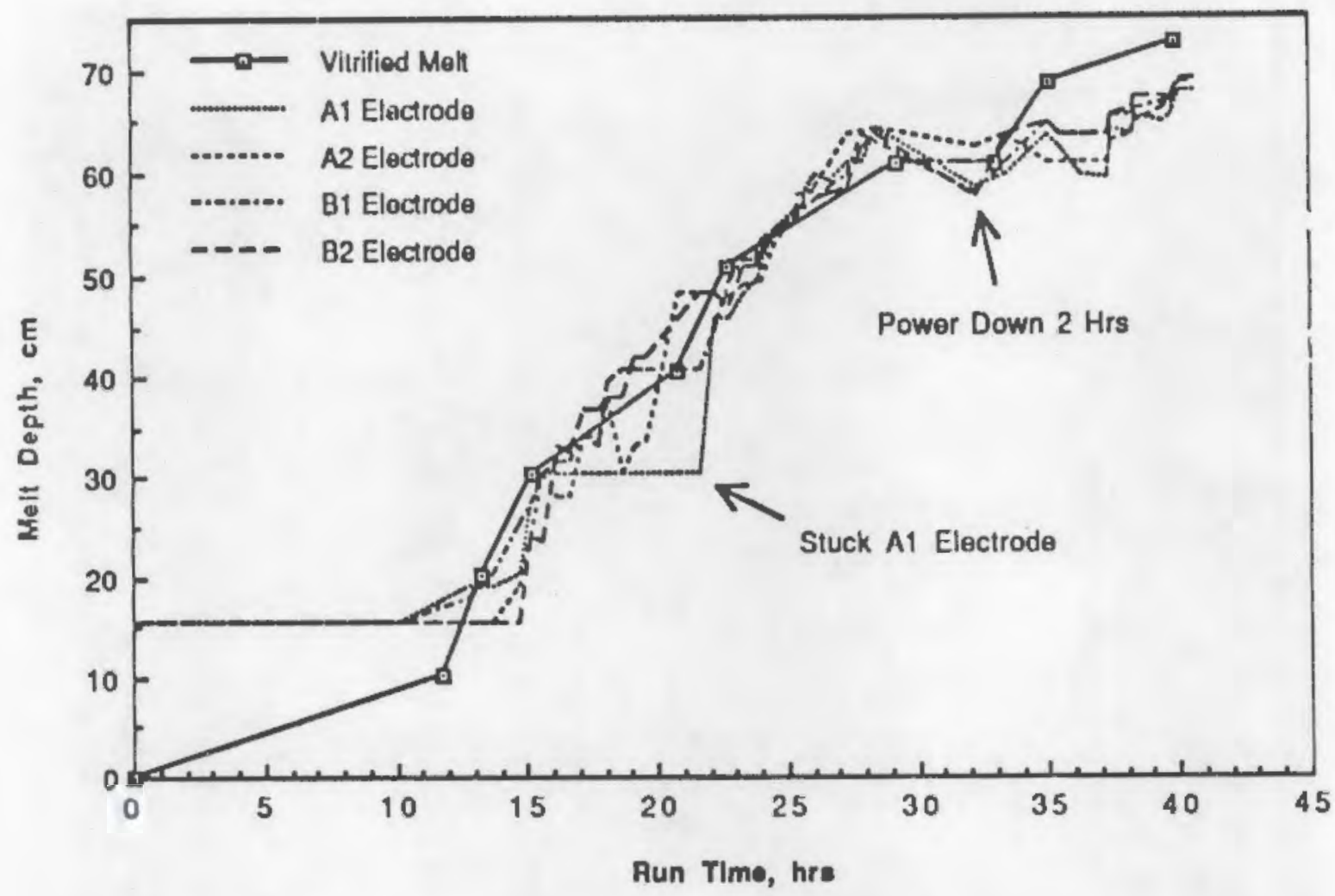

FIGURE 5.5. Melt Depth Versus Electrode Depth for ES-INEL-4

For the Zyp SC-coated electrodes (A-2 and B-2), the final lengths were only $65 \mathrm{~cm}$ (25.5 in.), $7.5 \mathrm{~cm}$ ( 3 in.) shorter than the original lengths. The necking down started $47 \mathrm{~cm}$ (19 in.) from the bottom, but formed a point at the bottom of each electrode. In addition, a more corroded area, with a diameter of $3.8 \mathrm{~cm}$ (1.5 in.), was observed $35 \mathrm{~cm}$ (14 in.) from the bottom of each electrode.

With each electrode experiencing the same type of start-up environment, the differences provide a direct comparison between the CVD-coated and the Zyp SC-coated electrodes. On the basis of this test, it appears that the more expensive CVD coating would provide better corrosion resistance than the Zyp SC coating. Nevertheless, tests conducted subsequent to this test have shown that coated electrodes are not necessary with electrode feeding provided the start-up time for the melt is not significantly long. 


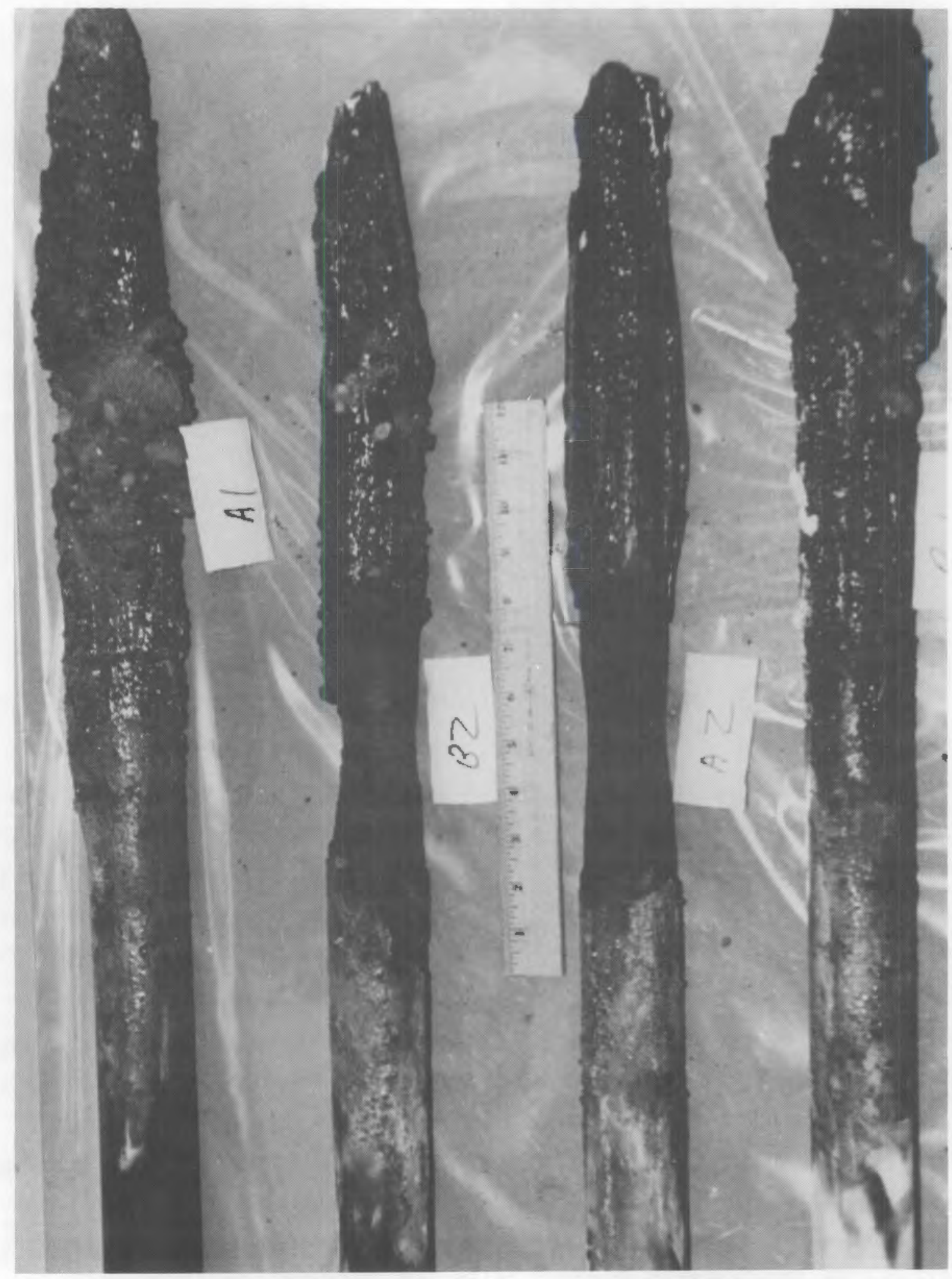

FIGURE 5.6. Posttest Observation of Electrode Corrosion from ES-INEL-4 


\subsection{ANALYTICAL RESULTS AND INTERPRETATION}

The posttest distribution of five volatile organic constituents and eight EP Tox metals within the glass and metal phases of the ISV block and within the surrounding soil are described in this section. Sample locations are generally shown by letters in Figure 4.2, although the relationship of the side soil samples to their temperature isotherms was somewhat hampered by the loss of thermocouple data after melting was completed. The concentrations of organic constituents were determined only in the soit zones around the ISV block because volatile organics in the glass and metal phases could not exist. Analyses for the EP Tox metals were performed for all three solid phases: glass, metal, and soil. In addition, EP Tox and/or TCLP tests for organics and metals were conducted on the glass, metal, and soil to determine if any of these components were regulated wastes according to EPA criteria. The cumulative masses of organic and EP Tox metals were determined in the off-gas equipment by determining concentrations of contaminants on samples of specific components and using known component masses or by estimating gas flow volumes. The off-gas components sampled were the insulation blanket, test container, off-gas line, and the filter and sorbent tube for organics and the filter and impinger solution for toxic metals. These masses were compared with the original amounts of materials placed in the test to estimate migration percentages. EG\&G performed a data validation on all laboratory test analytical results; ${ }^{(a)}$ the subsequent analyses used only validated data.

\subsection{QRGANIC CONSTITUENTS}

The concentration of volatile test organics in soil samples surrounding the melt is given in Table 6.1. Samples labeled $P$ through $J$ (as shown in Figure 4.2) were taken at successively lower isotherms away from the melt; samples $T$ and $U$ were taken below the basalt block. The concentrations of organics in these samples are uniformly low. The maximum equivalent concentration (EC) and halogenated hydrocarbon (HH) calculations for these samples

(a) Written communication from S. Pollard-Walker, INEL, to R. K. Farnsworth, PNL, dated June 26, 1990. 
TABLE 6.1. Concentration of Organics in Posttest Soil Samples Surrounding the Melt

\begin{tabular}{|c|c|c|c|c|c|c|c|}
\hline Organic & $\begin{array}{c}\text { Zone P } \\
\text { (melt edge) }\end{array}$ & Zone $\mathrm{N}$ & Zone $\mathrm{M}$ & Zone $\mathrm{K}$ & Zone $\mathrm{J}$ & $\begin{array}{l}\text { Zone T } \\
\left(125^{\circ} \mathrm{C}\right)\end{array}$ & $\begin{array}{l}\text { Zone U } \\
\left(80^{\circ} \mathrm{C}\right)\end{array}$ \\
\hline Ether, ppb & $\mathrm{d}^{(\mathrm{a})}$ & dl & 24 & dl & d 1 & $d t$ & 27 \\
\hline TCA, ppb & 8 & 8 & 8 & dl & d] & 6 & dl \\
\hline $\mathrm{CCl}_{4}, \mathrm{ppb}$ & dl & dl & $\mathrm{dT}$ & d) & dl & d] & dl \\
\hline TCE, ppb & d1 & d] & 6 & d) & dl & d1 & dl \\
\hline PCE, ppb & dl & dl & 30 & dl & d1 & dl & 6 \\
\hline$E C, \%(b)$ & $8 E-10$ & $8 E-10$ & $4.9 E-9$ & $<2 E-9$ & $2 E-9$ & $6 \mathrm{E}-10$ & $1.5 \mathrm{E}-9$ \\
\hline$H H, \%$ & $8 E-10$ & $8 \mathrm{E}-7$ & $4.7 \mathrm{E}-7$ & $<2 \mathrm{E}-6$ & $2 E-6$ & $6 \mathrm{E}-6$ & $1.2 \mathrm{E}-6$ \\
\hline
\end{tabular}

(a) $\mathrm{d} 1$ = detection limit $(5 \mathrm{ppb})$.

(b) Limiting values for unregulated waste are $0.001 \%(\mathrm{EC})$ and $0.01 \%(\mathrm{HH})$.

is $2 \times 10^{-9} \%$ and $6 \times 10^{-6} \%$, respectively. These concentrations are significantly less than the EC and HH limits for unregulated waste $(0.001 \%$ and $0.01 \%$ respectively) as defined by the EPA spill table (40 CFR Table 302.4). The EC values are calculated as the sum of the toxic constituents in the waste mixture, weighted according to the degree of toxicity as defined in the spill table. The HH values are calculated as the sum of the percentage of halogeated hydrocarbons in a waste mixture. The results show that the soil samples from ES-INEL-4 can be considered nonregulated from an organic standpoint. The results of TCLP-ZHE tests on the same samples are shown in Table 6.2. About half of the TCLP results are below the detection limit for gas chromatography/ mass spectrometry (GC/MS) techniques, and all samples are nonregulated according to $\mathrm{EC}$ and $\mathrm{HH}$ criteria and have, therefore, been rendered nonhazardous.

The soil sample at zone $M$, which included the $100^{\circ} \mathrm{C}$ isotherm, yielded the highest TCLP values (see Figure 4.2). Samples beyond this zone were consistently lower suggesting that no outward migration of organics occurs outside of the $100^{\circ} \mathrm{C}$ soil isotherm. Since all but PCE are generaliy volatile below $100^{\circ} \mathrm{C}$, this supports the theory of molecular diffusion of organics 
TABLE 6.2. TCLP-ZHE Analysis for Organics in Posttest Soils

\begin{tabular}{|c|c|c|c|c|c|c|c|c|}
\hline Organic & sal & $\begin{array}{c}\text { Zone P } \\
\text { (melt edge) }\end{array}$ & Zone $\mathrm{N}$ & Zone M & Zone $\mathrm{K}$ & Zne $\mathrm{J}$ & $\begin{array}{r}\text { Zone T } \\
125^{\circ} \mathrm{C}\end{array}$ & $\begin{array}{r}\text { Zone U } \\
80^{\circ} \mathrm{C}\end{array}$ \\
\hline $\begin{array}{l}\text { Ether, ppb } \\
\text { TCA, ppb } \\
\text { CCL } 4 \text { ppb } \\
\text { TCE, ppb } \\
\text { PCE, ppp } \\
\text { EC, \% } \\
\text { HH, \% }\end{array}$ & $\begin{array}{l}\text { dl (a) } \\
\text { d } 7 \\
\text { dl } \\
\text { d } 1 \\
\text { d } 7 \\
\text { d } 7 \\
\text { dl }\end{array}$ & $\begin{array}{l}d 1 \\
d 7 \\
13 \\
6 \\
d 7 \\
29 E-9 \\
2.9 E-9\end{array}$ & $\begin{array}{l}\text { d1 } \\
6 \\
32 \\
11 \\
8 \\
5.8 \mathrm{E}-9 \\
5.7 \mathrm{E}-6\end{array}$ & $\begin{array}{l}18 \\
17 \\
128 \\
67 \\
34 \\
2.5 E-8 \\
2.5 E-5\end{array}$ & $\begin{array}{l}\text { dl } \\
\text { dl } \\
\text { dl } \\
\text { dl } \\
\text { dl } \\
13 E-10 \\
13 E-7\end{array}$ & $\begin{array}{l}\text { dl } \\
\text { dl } \\
17 \\
6 \\
\text { d1 } \\
3.5 E-9 \\
3.0 E-6\end{array}$ & $\begin{array}{l}\text { dl } \\
\text { dl } \\
\text { d } 1 \\
\text { d } 1 \\
\text { dl } \\
2 E-9 \\
2 E-6\end{array}$ & $\begin{array}{l}d 1 \\
d 1 \\
d 1 \\
d 1 \\
d 1 \\
16 E-10 \\
16 E-6\end{array}$ \\
\hline
\end{tabular}

(a) $\mathrm{dl}=$ detection 1 imit $(5 \mathrm{ppb})$.

(b) Limiting values for unregulated waste are $0.001 \%$ (EC) and $0.01 \%(\mathrm{HH})$. 
toward the melt, followed by pyrolysis and combustion. A more detailed discussion of this process is described in a report by Timmerman and Peterson (1990).

Determination of uncombusted organic concentrations in the off gas was not successful for ether, TCA, and $\mathrm{CCl}_{4}$ because these materials broke through the sorbent resin tubes. Also, during analysis of the resin tubes, concentrations exceeded the preset GC/MS instrument range for these components so the total mass could not be determined. The other two volatile organics, TCE and PCE, broke through the first sorbent resin tube, but not the second. As a result, complete mass balances could only be determined on TCE and PCE. Based on this experience, it is recommended that a different method of organic offgas sampling be used. Currently the proposed organic sampling method considers use of the T0-14 procedure, which uses an evacuated SUMMA canister in conjunction with a critical orifice meter to collect a sinall volume of the total offgas flow that is representative of the average off gas over the entire ISV test.

The transport of four of the listed volatile organics is summarized in Table 6.3, which indicates percentages of organics transported to soils, removed for capture by the off-gas system, and destroyed-by pyrolysis and combustion. Because of the breakthrough problem, only limiting values can be determined for TCA and $\mathrm{CCl}_{4}$; more than $96 \%$ of the TCE and PCE components were destroyed, and the remainder was effectively captured by the off-gas system. In all cases, the amount transported to the soils was negligible. Ether is not included in this table because, while flammable, it is not a listed waste and it also had the most analytical uncertainty due to sorbent tube

TABLE 6.3. Mass Balances of Volatile Organics

\begin{tabular}{|c|c|c|c|}
\hline $\begin{array}{c}\text { Organic } \\
\text { Constituent } \\
\end{array}$ & $\begin{array}{l}\text { Transported } \\
\text { to Soil, } \frac{\%}{6}\end{array}$ & $\begin{array}{c}\text { Removed for } \\
\text { Capture by } \\
\text { Off-Gas System, } \% \\
\end{array}$ & Destroyed, $\%$ \\
\hline TCA & 0.04 & $>11$ & $<89$ \\
\hline $\mathrm{CCl}_{4}$ & $<0.04$ & $>2.7$ & $<97$ \\
\hline TCE & 0.005 & 3.2 & 96.8 \\
\hline PCE & 0.13 & 3.2 & 96.7 \\
\hline
\end{tabular}


breakthrough and high volatility. In spite of the sampling problems, these results indicate that most of the organics were destroyed and a minor fraction was volatilized for capture by the off-gas system. Test results indicated that ES-INEL-4 was successfui in the destruction and removal of the organic components initially placed in the test, that sorbent tube resins alone may not be sufficient, and that a more controllable sampling system should be considered in future tests.

In comparing the destruction and removal efficiencies (DREs) of ISV to other technologies, it should be noted that efficiencies are calculated on a comparable basis. DREs of hazardous remediation technologies are calculated by dividing the mass of volatilized or entrained material released to the atmosphere by the mass of organic materials actualiy processed. Accordingly, the DRES for ISV processing are determined by the amount of volatilized or entrained material released by the ISV off-gas system divided by the amount of organic material that was processed by ISV. DREs do not consider that amount of material transported to the surrounding soil where the only concern is if the amount of contamination released to the soils is large enough to make them hazardous. In ES-INEL-4, all soils were well below hazardous limits. Sampling and analysis uncertainties did not permit calculation of DREs for organics in the off-gas system in ES-INEL-4. However, based only on removal efficiencies of activated carbon sorbents, the ISV off-gas system is designed to retain $99.9 \%$ of the volatile organic contamination. This design criteria implies that any release of contaminants to the off-gas system of $10 \%$ or less of the material processed will result in a DRE of $99.99 \%$. of the four volatile organics listed in Table 6.3, all are within this 1 imit (99.99\%) except for TCA, which is very close at $99.989 \%$. If a scrubber is also included in the system, these efficiencies will be improved.

\subsection{EP TOX METALS}

The posttest concentrations of the eight EP Tox metals in the vitrified glass, metal, and the posttest soils and basalt rock are given in the tables discussed in this section. These components were also tested by EP Tox and/or TCLP procedures. 
Average values of the EP Tox metals in the glass block along with the TCLP and EP Tox test results are compared with the maximum allowable leach concentrations in Table 6.4. The TCLP test was conducted on crushed samples, which yields maximum values. A second test was conducted on monolith samples, which is more realistic for a glass block and yielded lower results as expected. Both test results were well below maximum allowable leach limits, however. $\mathrm{Ba}, \mathrm{Cr}$, and $\mathrm{Pb}$ exhibited the highest concentrations of the eight metals in the glass and also were highest in the leach test results. $\mathrm{Hg}$ was essentially undetectable in the glass and probably volatilized early during the melting process. Analysis of the heavy metals in the glass phase indicates that the ISV block can be considered nonregutated based on the TCLP and EP Tox results. Moreover, the glass block generated by the ISV process demonstrates excellent qualities of heavy metal retention.

The glass block was sampled vertically (as indicated in Figure 4.2) with sample A collected near the top of the block and with sample $D$ the deepest sample. Separate borings into the block within the area between the electrodes were used to obtain samples, so there is some lateral separation among samples. The concentration of EP Tox metals in these samples is given in Table 6.5 to indicate the variability of inorganics in the block. A second "A" sample was also taken in the upper $A$ region near the first $A$ sample and the results for both are given. The second sample apparentiy contained some metallic phase that yielded high values for $\mathrm{Ag}, \mathrm{Cr}, \mathrm{Pb}$, and $\mathrm{Cd}$. Other

IABLE 6.4. Toxic Metal Concentrations in the Vitrified Glass from TCLP and EP Toxicity Testing

\begin{tabular}{|c|c|c|c|c|}
\hline Element & $\begin{array}{c}\text { Average } \\
\text { Concentration, } \\
\text { ppb. } \\
\end{array}$ & $\begin{array}{l}\text { TCLP, } \\
\mathrm{ppb}\end{array}$ & $\begin{array}{c}\text { EP Toxicity, } \\
\mathrm{ppb} \\
\end{array}$ & $\begin{array}{c}\text { Maximum Allow- } \\
\text { able Leach } \\
\text { Concentration, } \\
\text { ppb }\end{array}$ \\
\hline $\begin{array}{l}\mathrm{Ag} \\
\mathrm{As} \\
\mathrm{Ba} \\
\mathrm{Cd} \\
\mathrm{Cr} \\
\mathrm{Hg} \\
\mathrm{Pb} \\
\mathrm{Se}\end{array}$ & $\begin{array}{c}65.8 \\
3.2 \\
1,089 \\
3.9 \\
722 \\
0.12 \\
352 \\
38.4\end{array}$ & $\begin{array}{r}<23 \\
<168 \\
229 \\
7.8 \\
17.8 \\
<0.1 \\
636.4 \\
<98\end{array}$ & $\begin{array}{c}<15 \\
<108 \\
49 \\
8.4 \\
<9 \\
<0.1 \\
<116 \\
<98\end{array}$ & $\begin{array}{r}5,000 \\
5,000 \\
100,000 \\
1,000 \\
5,000 \\
200 \\
5,000 \\
1,000\end{array}$ \\
\hline
\end{tabular}


IABLE 6.5. EP Tox Metal Concentration Ranges in Glass

\begin{tabular}{|c|c|c|c|c|c|c|c|c|}
\hline \multirow[b]{2}{*}{ Sample ${ }^{(a)}$} & \multicolumn{8}{|c|}{ Concentration Ranges, ppm } \\
\hline & $\mathrm{Ag}$ & As & $\mathrm{Ba}$ & Cd & $\mathrm{cr}$ & $\mathrm{Hg}$ & $\mathrm{Pb}$ & $\mathrm{Se}$ \\
\hline A & $\frac{30-}{115}$ & $\begin{array}{r}5.7- \\
15.9\end{array}$ & $\begin{array}{l}1042- \\
1046\end{array}$ & $\begin{array}{r}7.2- \\
19.5\end{array}$ & $\begin{array}{r}388- \\
1288\end{array}$ & 0.23 & $\begin{array}{l}126- \\
631\end{array}$ & $\begin{array}{l}31.4- \\
40.2\end{array}$ \\
\hline B & 64.3 & 4.0 & 1134 & 7.2 & 734 & 0.05 & 306 & 52.2 \\
\hline c & 58.8 & 4.5 & 1062 & 7.6 & 460 & 0.05 & 405 & 29.7 \\
\hline D & 60.0 & 3.9 & 1161 & 7.0 & 739 & 0.06 & 290 & 61.5 \\
\hline
\end{tabular}

(a) See Figure 4.2 for sampie locations

elements such as $\mathrm{Ba}$, which tend to accumulate in glass rather than metal, show fairly uniform concentration. In general, there has been no vertical segregation of EP Tox metals in the glass block that is greater than possible lateral variation.

Average concentrations of EP Tox metals in the metallic phase, along with the average results of TCLP tests for three samples, are given in Table 6.6 and compared with maximum allowable TCLP leach test limits for regulated waste. The results of an additional sample were rejected as suspect (with $90 \%$ confidence) because of dissimilarities with the others using a 0 test [as described by Day and Underwood (1967)]. The rejection did not alter the observation that leach test results for $\mathrm{Pb}$ exceed the concentration 1 imits for nonregulated waste. As expected, due to the general reducing nature of the ISV system, the concentration of some EP Tox metallic elements in the metallic phase is higher than in the glass. Pb probably exists as a separate metallic phase, which may contribute to the unacceptable TCLP results for $\mathrm{Pb}$. Part of the reason for this is that most of the metal phase is a ferrous alloy steel, and $\mathrm{Pb}$ does not alloy with this material. In ES-INEL-4, meta11ic Pb was placed in the test and under more oxidizing conditions more of the $\mathrm{Pb}$ could possibly dissolve in the glass phase.

The equilibrium oxidation of $\mathrm{Pb}$ as a function of temperature is compared with $\mathrm{Fe}$ oxidation in Figure 6.1. This comparison indicates that the $\mathrm{Pb}-\mathrm{PbO}$ boundary occurs between the $\mathrm{Fe}-\mathrm{Fe}_{3} \mathrm{O}_{4}$ and $\mathrm{Fe}_{3} \mathrm{O}_{4}-\mathrm{Fe}_{2} \mathrm{O}_{3}$ boundaries, so that in 
TABLE 6.6. EP Tox Metals in the Metallic Phase

\begin{tabular}{|c|c|c|c|c|}
\hline Metal & $\begin{array}{c}\text { Average } \\
\begin{array}{c}\text { Concentration, } \\
\text { ppm }\end{array} \\
\end{array}$ & $\begin{array}{c}\text { TCLP } \\
\text { Average, } \\
\text { ppm }\end{array}$ & $\begin{array}{l}\text { Detect ion } \\
\text { Limit }\end{array}$ & $\begin{array}{c}\text { Maximum Allow- } \\
\text { able Conc., } \\
\text { ppm }\end{array}$ \\
\hline $\begin{array}{l}\mathrm{Ag} \\
\mathrm{As} \\
\mathrm{Ba} \\
\mathrm{Cd} \\
\mathrm{Cr} \\
\mathrm{Hg} \\
\mathrm{Pb} \\
\mathrm{Se}\end{array}$ & $\begin{array}{c}80.8 \\
1350 \\
3.4 \\
6.6 \\
28500 \\
0.06 \\
1480 \\
58.5\end{array}$ & $\begin{array}{l}\mathrm{d} 1 \\
\mathrm{~d} 1 \\
0.082 \\
0.028 \\
1.7 \\
\mathrm{~d} 1 \\
23.9 \\
0.076\end{array}$ & $\begin{array}{l}0.023 \\
0.16 B\end{array}$ & $\begin{array}{r}5 \\
5 \\
100 \\
1 \\
5 \\
0.2 \\
5 \\
1\end{array}$ \\
\hline
\end{tabular}

the presence of metallic $\mathrm{Fe}, \mathrm{Pb}$ will tend to be in the metallic form. In order for $\mathrm{Pb}$ to dissolve in the melt it must oxidize and if the redox state of the system prevents this, $\mathrm{Pb}$ will occur as a separate phase. Under nonequilibrium conditions or local oxidation, however, some $\mathrm{Pb}$ can dissolve in the melt. If a separate $\mathrm{Pb}$ phase becomes a problem in ISV applications, the possibility of preoxidation or incorporation of $\mathrm{Pb}$ into other glass phases such as phosphates may be considered. Larger scale ISV melts may aiso enhance oxidation and dissolution of $\mathrm{Pb}$ into the vitrified $\mathrm{glass}$ by allowing more time for oxidation and dissolution to occur.

EP Tox and TCLP test results of the EP Tox metals in posttest soil samples are given in Table 6.7; heavy metal concentrations in posttest soils are given in Table 6.8. In a11 cases except one, leach test results for heavy metals in posttest soil samples are below the level of designated wastes and are nonhazardous. However, leach tests indicated that the soil sample at the edge of the melt (zone P) yieids unacceptable Cd values. This result may be due to the potential reduction of $C d$ oxide to $\mathrm{Cd}$ metal coupled with the low boiling point $\left(-700^{\circ} \mathrm{C}\right)$ for $\mathrm{Cd}$ metal. Even though the $\mathrm{Cd}$ concentrations in this zone are above maximum allowable leach zone extraction levels, the cd concentrations in the soil leachate are reduced by 2.5 times from those of the contaminated pretest soils. Larger ISV tests may result in lower leach rate 


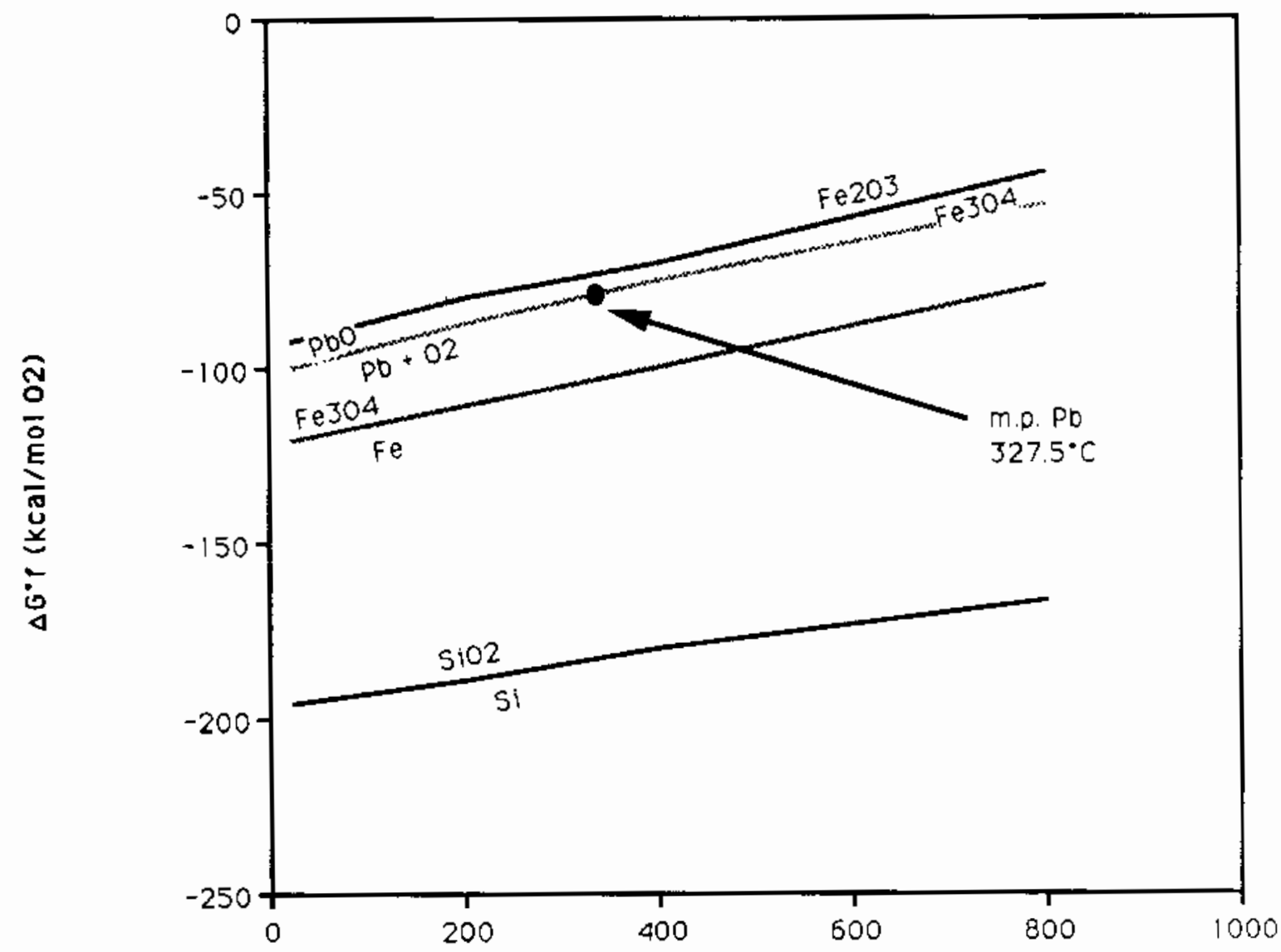

Temperature $(\cdot c)$

\section{EIGURE 6.1. Comparison of Pb Oxidation with Fe Oxidation}

for soil near the melt edge. This behavior needs further analysis and evaluation for applications to buried heavy metal. In sumnary, except for one sample near the melt edge, a11 the posttest soils pass EPA leach test criteria for nonregulated materials.

Because of the heterogeneous nature of the molten metal pool, an accurate mass balance of the EP Tox metals between the glass and metal phase could not be made. Qualitatively, however, it was observed that $\mathrm{Hg}$ and Se accumulated in the off-gas system and $\mathrm{Pb}$ accumulated in the insulating blanket and filter, probably as particulates. The metals did not migrate to the soils and were generally confined to the vitrified glass or metal phases. 
TABLE 6.7. Worst-Case EP Tox and TCLP Data for Posttest Soils

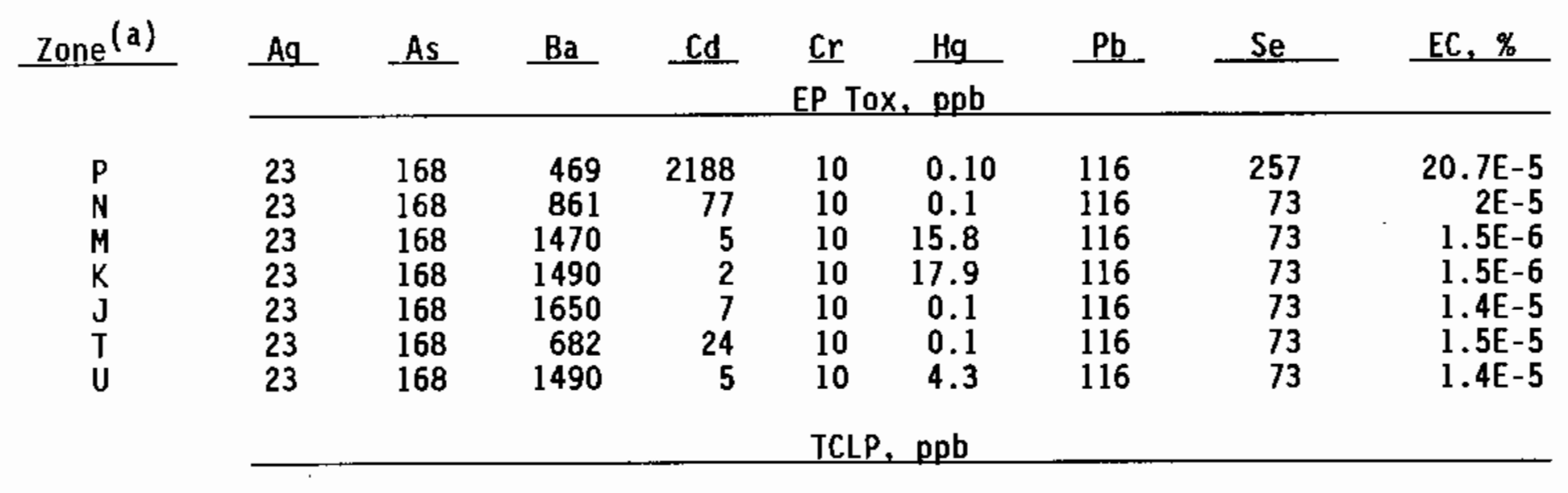

$\stackrel{\circ}{\dot{0}}$

$\begin{array}{lllrrrrrrr}\mathrm{P} & 23 & 168 & 742 & 1947 & 9 & 0.1 & 116 & 254-303 & 20.7 \mathrm{E}-5 \\ \mathrm{~N} & 23 & 168 & 1427 & 59 & 9 & 0.4 & 116 & 114 & 1.9 \mathrm{E}-6 \\ \mathrm{M} & 23 & 168 & 1714 & 5 & 9 & 27.6 & 116 & 98 & 1.6 \mathrm{E}-5 \\ \mathrm{~K} & 23 & 168 & 2079 & 12 & 9 & 30 & 116 & 98 & 1.7 \mathrm{E}-5 \\ \mathrm{~J} & 23 & 168 & 1720 & 5 & 9 & 0.8 & 116 & 98 & 1.3 \mathrm{E}-5 \\ \mathrm{~T} & 23 & 168 & 906 & 21 & 9 & 0.8 & 116 & 98 & 1.5 \mathrm{E}-5 \\ \mathrm{U} & 23 & 168 & 1742 & 8 & 9 & 17.1 & 116 & 98 & 1.5 \mathrm{E}-5\end{array}$

Max. Allow-

able Leach

Concentra-

$\begin{array}{lllllllll}\text { tion, ppb } & 5000 & 5000 & 100000 & 1000 & 5000 & 200 & 5000 & 1000\end{array}$

(a) Refer to Figure 4.2 for zone locations. 
IABLE 6.8. Worst-Case Concentration of Toxic Metals in Posttest Soils, ppm

\begin{tabular}{|c|c|c|c|c|c|c|c|}
\hline tal & $\begin{array}{l}\text { Zone } p^{(a)} \\
\text { Melt Edge }\end{array}$ & Zone $\mathrm{N}$ & Zone $M$ & Zone $\mathrm{K}$ & Zone $\mathrm{J}$ & $\begin{array}{l}\text { Zone }{ }^{\top} \\
125^{\circ} \mathrm{C}\end{array}$ & $\begin{array}{l}\text { Zone } \mathrm{C} \\
80^{\circ} \mathrm{C} \\
\end{array}$ \\
\hline $\begin{array}{l}\mathrm{Hg} \\
\mathrm{Pb}\end{array}$ & $\begin{array}{c}<2.3 \\
31.5 \\
80.7 \\
89.85 \\
5.9 \\
0.9 \\
35 \\
<2.3\end{array}$ & $\begin{array}{r}<2.3 \\
<16.8 \\
138 \\
53.1 \\
13.7 \\
3.5 \\
18.3 \\
11.5\end{array}$ & $\begin{array}{r}<2.3 \\
<16.7 \\
162 \\
1.7 \\
16.5 \\
7.3 \\
14.7 \\
<7.2\end{array}$ & $\begin{array}{c}<2.3 \\
<17.1 \\
201 \\
0.61 \\
18.9 \\
4.7 \\
20.2 \\
<7.4\end{array}$ & $\begin{array}{r}<2.3 \\
<18.9 \\
206 \\
1.4 \\
19.8 \\
2.5 \\
21.3 \\
<8.2\end{array}$ & $\begin{array}{r}<2.3 \\
<16.6 \\
148 \\
15.5 \\
18.3 \\
1.4 \\
12.6 \\
12.9\end{array}$ & $\begin{array}{r}<2.3 \\
<16.9 \\
196 \\
1.3 \\
18.2 \\
6.4 \\
19.5 \\
<7.3\end{array}$ \\
\hline
\end{tabular}

(a) Refer to Figure 4.2 for zone locations. 


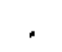

$\because$

- 


\subsection{REFERENCES}

Charboneau, B. L., K. A. Kearney, R. N. Currie, C. E. Bigelow, and R. K.

Farnsworth. 1989. In Situ Vitrification Engineering Scale Test ES-INEL-4 Sampling and Analysis P7an. EGG-WM-8662, EG\&G Idaho, Inc., Idaho National Engineering Laboratory, Idaho Falls, Idaho.

Day, R. A., Jr., and A. L. Underwood. 1967. Quantitative Analysis, PrenticeHa11, New Jersey.

Farnsworth, R. K., K. H. Oma, and C. E. Bigelow. 1990. Initial Tests on In Situ Vitrification Using Electrode Feeding Techniques. PNL-7355, Pacific Northwest Laboratory, Richland, Washington.

Oma, K. H, M.A.H. Reimus, and C. L. Timmerman. 1989. Support for the In Situ Vitrification Treatability Study at the Idaho National Engineering Laboratory: FY 1988 Summary. PNL-6787, Pacific Northwest Laboratory, Richland, Washington.

Timmerman, C. L., and M. E. Peterson. 1990. Pilot-Scale Testing of In Situ Vitrification of Arnold Engineering Development Center Site 10 Contaminated Soils. PNL-7211, Pacific Northwest Laboratory, Richland, Washington. 


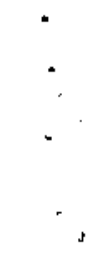




\section{DISTRIBUTION}

No. of

Copies

OFFSITE

12 DOE/Office of Scientific and Technical Information

T. B. Hindman, DP 12

DOE Office of Defense Programs

GTN

Washington, DC 20545

H. G. Walter, EM-343

DOE Office of Waste Operations GTN

Washington, DC 20545

6 DOE Office of Environmental

Restoration and Waste

Management

Forrestal Building

Washington, DC 20585

ATTN: J. A. Coleman, EM-35

C. R. Cooley, EM-55

T. D. Anderson, EM-442

C. Frank, EM-50

S. Prestwich, EM-52

S. P. Mathur, EM-54

J. Arthur

DOE Albuquerque Operations Office

P.0. Box 5400

A1buquerque, NM 87185

E. Maestas

DOE West Valley Project

P.0. Box 191

West Valley, NY 14171

3 DOE Idaho Operations Office

785 DOE Place

Idaho Falls, ID 83402

ATTN: J. P. Hamric

M. W. Shupe

S. A. Morreale
No. of

Copies

10

B. L. Charboneau

Wastren, Inc.

477 Shoup Ave., Suite 209

Idaho FaTls, ID 83402

W. T. Goldston

DOE Savannah River Operations Office

P.0. Box A

Aiken, SC 29801

M. J. Steindler, CMT-205

Argonne National Laboratory

9700 South Cass Avenue

Argonne, IL 60439

2 Battelle Memorial Institute

$505 \mathrm{King}$ Avenue

Columbus, $\mathrm{OH} 43201$

ATTN; W. A. Carbeiner

R. A. Nathan

L. D. Ramspott, L209

Lawrence Livermore National Laboratory

University of California

P.0. Box 808

Livermore, CA 94550

M.A.H. Reimus

Los Alamos National Laboratory

P.0. Box 1663

Los Alamos, NM 87545

4 Oak Ridge National Laboratory

P.0. Box Y

Oak Ridge, TN 37830

ATTN: G. K. Jacobs

L. J. Mezga

T. A. Row

B. P. Spalding 
No. of

Copies

15 EG\&G Idaho

P.0. Box 1625

Idaho Falls, ID 83415

ATTN: S. 0. Bates

R. K. Farnsworth (10)

J. L. Landon

S. K. Merrill

R. M. Schletter

J. R. Weidner

2 Sandia Laboratories

P.0. Box 5800

Albuquerque, NM 87185

ATTN: R. W. Lynch

Technical Library

5 Westinghouse Savannah River

Company

Savannah River Site

Bldg. 704-S

Aiken, SC 29801

ATTN: J. Haselow

C. M. Jantzen

M. J. Plodinec

J. F. Sproul1

J. Steele

J. M. Pope

West Valley Nuclear Services Company

P.0. Box 191

West Valley, NY 14171

4 Geosafe Corporation

Kirk? and Park Place

303 Park Place, Suite 126

Kirkland, WA 98033

ATTN: V. F. FitzPatrick

C. L. Timmerman

J. G. Carter

B. E. Campbell

J. Harris

Embassy of Australia

1601 Massachusetts Ave. NW

Washington, DC 20036
No. of

Copies

ONSITE

8 DOE Richland 0perations office

E. A. Bracken, A6-95

G. J. Bracken, A6-80

P. K. Clark, A6-80

P. F. Dunigan, A6-95

M. J. Furman, $A 6-80$

R. E. Gerton, $A 6-80$

R. 0. Izatt, $A 6-95$

J. J. Sutey, A5-90

10 Westinghouse Hanford Company

J. W. Cammann, H4-54

K. R. Fecht, H4-56

R. E. Lerch, B2-35

H. E. McGuire, B2-35

J. L. Scott, R2-87

J. C. Sonnichsen, H4-54

0 . A. Turner, R1-10

D. D. Wodrich, Rl-48

R. 0. Wojtasek, B2-15

B. A. Wolfe, L5-61

34 Pacific Northwest Laboratory

T. Bergsman, P7-44

C. E. Bige ow, P7-44

W. F. Bonner, P7-44

T. M. Brouns, P7-44

J. L. Buelt, P7-44

H. C. Burkholder, $P 7-41$

C. C. Chapman, P7-41

R. D. Gibby, P7-44

C. H. Kindle, P7-44

0. E. Knowlton, P7-40

S. S. Koegler, P7-44

J. L. McElroy, P7-46

K. A. Parne11, P7-18

M. E. Peterson, P7-44

T. D. Powe17, P7-44

J. W. Shade (10), P8-37

J. A. Stottlemyre, $\mathrm{K} 6-78$

L. E. Thompson, P7-44

J. S. Tixier, P7-44

Publishing Coordination

Technical Report Files (5) 